\title{
Borehole, surface geologic, and geotechnical data for the Aspen Grove landslide, Sanpete County, Utah
}

Rex L. Baum and Robert W. Fleming

U.S. Geological Survey Open-File Report 01-413

This report is preliminary and has not been reviewed for conformity with U.S. Geological Survey editorial standards nor with the North American Stratigraphic Code. Any use of trade names in this publication is for descriptive purposes only and does not imply endorsement by the U.S. Government. 


\section{Introduction}

$\mathrm{T}$ The Aspen Grove landslide, in Ephraim Canyon,

Sanpete County, Utah (fig. 1) was active from 1983 through 1987 and was the subject of field investigations from 1983-1986. Previous reports included some of the borehole, geologic, and geotechnical data collected as part of these investigations but many of the data have not previously been published (Baum, 1988; Baum and others, 1988; Baum and Fleming, 1989; Fleming and Johnson, 1989; Baum and others, 1993; Baum and Reid, 2000). Plans to pave Utah State Highway 29, which crosses the landslide in two places, has led to a recent request to make these data available. This report includes a geologic description of the landslide and its immediate surrounding area, borehole logs, piezometric observations, and laboratory data from the landslide.

\section{Topographic and Geologic Setting}

The head of the Aspen Grove landslide is at about $2,423 \mathrm{~m}$ (about 7,950 ft) altitude in an assemblage of spruce, fir, aspen, and maple (fig. 1). The toe is at about 2,240 m (about 7,350 ft) altitude in an assemblage of scrub oak and sagebrush. Grasses and shrubs cover the ground surface, and boulders of sandstone jut out of the ground.

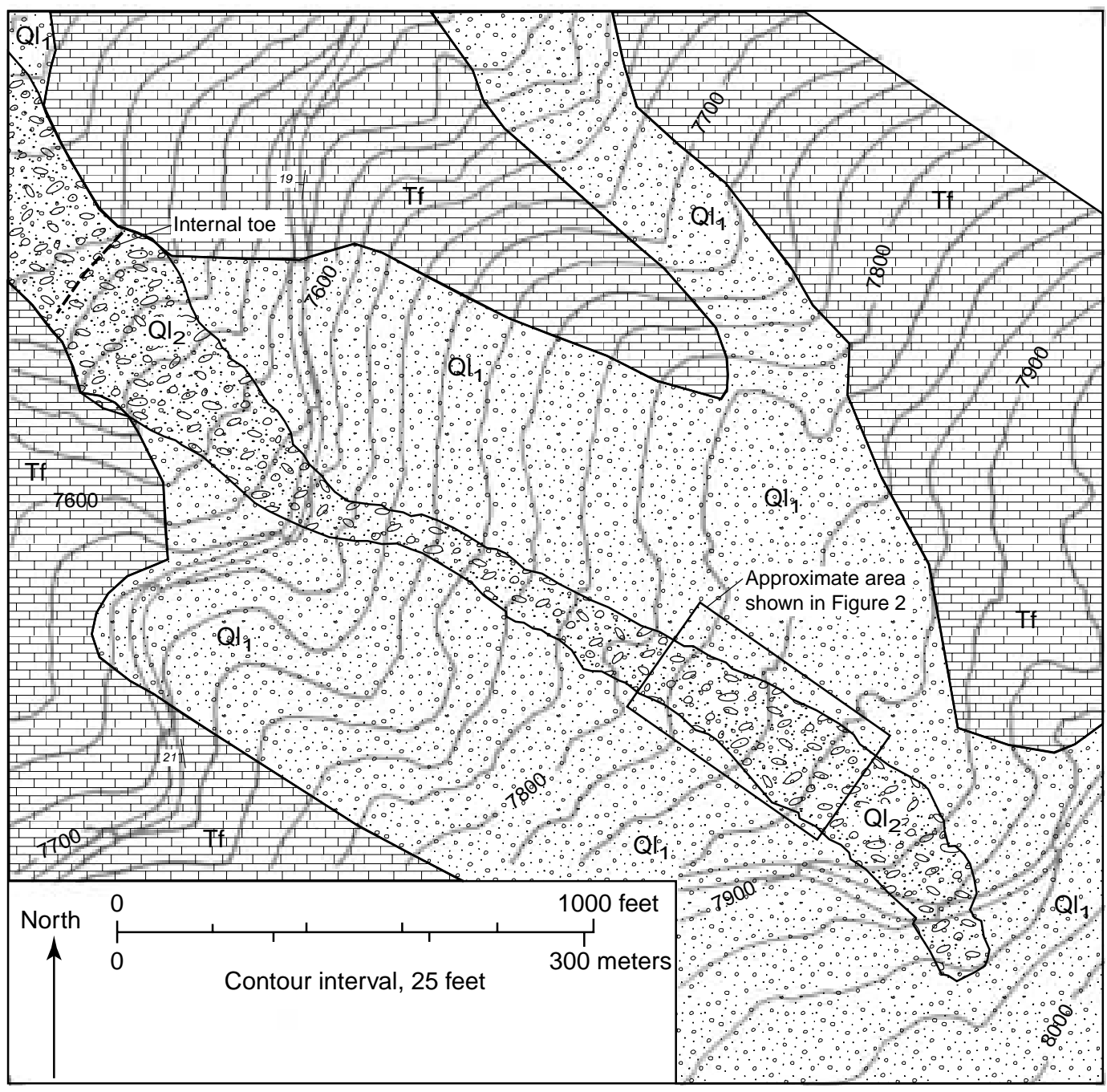

Explanation of Map Units

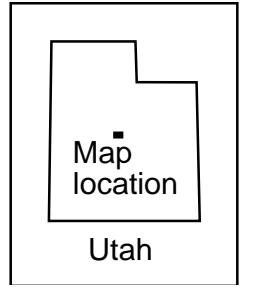

$\mathrm{QI}_{2} \quad$ Landslide deposits of the Aspen Grove landslide

Q ${ }_{1} \quad$ Landslide deposits and colluvium that predate the Aspen Grove landslide

TfI

Flagstaff limestone, generally blanketed by $0.5-2 \mathrm{~m}$ of weatherred residuum. 
The slope of the ground in the vicinity of the landslide ranges from $0^{\circ}$ to $31^{\circ}$ and averages about $11^{\circ}$. The ground slopes generally toward the west. Superimposed on the westerly slope of the area are plunging ridges and troughs in the ground surface that trend west or northwest (fig. 1). The ridges are 100 to $200 \mathrm{~m}$ wide and hundreds of meters long. The troughs are of the same length, but are about half as wide as the ridges. Relief on the troughs and ridges is about 10 to $50 \mathrm{~m}$. The troughs and ridges result from relief on the surface of the bedrock, because bedrock crops out at the crests of many of the ridges. The trend of the troughs and ridges is oblique to the strike of the bedrock.

\section{Bedrock}

B edrock in the area consists of bedded limestone, limy sandstone, and shale of the Cove Mountain and Musina Peak Members of the Flagstaff Limestone (Stanley and Collinson, 1979), and sandstone and shale of the North Horn Formation. Figure 1 shows the distribution of bedrock formations and surficial deposits near the slide (see also Plate 1 of Baum and Fleming, 1989). The Flagstaff Limestone underlies ground in the vicinity of the Aspen Grove landslide, and the North Horn Formation underlies an escarpment east of the landslide.

Limestone of the Cove Mountain Member of the Flagstaff Limestone is white or gray, porous, and lacks fossils. Some brown chert occurs with the limestone. Limestone of the Musina Peak Member contains abundant mollusk fossils and is white or gray and finegrained. Some of the limestone is silicified. Sandstone occurs only in the Cove Mountain Member; it is white or light gray and moderately indurated. The sandstone consists of fine- to medium-grained, pink and white quartz sand with calcite cement. Shale in both members is compact and gray, white, brown, or red claystone.

The North Horn Formation southeast of the landslide consists of 1- to 3-m-thick beds of ledge-forming sandstone, alternating with beds of claystone and a few 0.1to 0.3 -m-thick beds of limestone. The sandstone is light gray or light yellow, massive or cross laminated, and consists of quartz sand mixed with a few chert granules and cemented by silica. The claystone is red, brown, orange, or gray, massive and silty. The limestone is medium- to dark-gray, and fossiliferous.

The bedding in the Flagstaff Formation, which underlies the area of Aspen Grove landslide, dips about $20^{\circ}$ toward the west. The structures in the area include a fault at the foot of the escarpment (east of Aspen Grove, see Baum and Fleming, 1989). The fault dips steeply toward the west and trends about N. $10^{\circ}$ E. Beds of the Flagstaff Limestone, west of the fault, are down relative to beds of the North Horn Formation, east of the fault. The North Horn beds are about horizontal. Another fault is in Flagstaff Limestone, near the presumed terminus of the Aspen Grove landslide. The fault trends about due north and dips steeply or is vertical. Beds are down on the east side of the fault.

\section{Residuum}

$\mathrm{T}$ The area of the Aspen Grove landslide is blanketed by weathered residuum in some places and by colluvium or landslide debris in others. The residuum is material derived from the underlying bedrock of the Flagstaff Limestone by weathering essentially in place. It is generally 0.5 to $2 \mathrm{~m}$ thick. The residuum is predominantly clay, and contains abundant pebble-, cobble-, and boulder-sized clasts. The clasts include white or gray limestone; white, silicified, fossiliferous limestone; white or gray limy sandstone; and light gray, red, or green claystone. ${ }^{1}$

\section{Landslide Debris}

$\mathrm{T}$ The matrix of the landslide debris in the area of the Aspen Grove landslide consists of yellow or brown, sandy clay and contains abundant boulders and blocks of cross-laminated yellow and light-gray sandstone derived from the North Horn Formation. The sandstone boulders and blocks in the landslide debris consist of fine- to medium-grained, moderately sorted quartz sand with granules and pebbles of white chert. The sandstone has silica cement and does not effervesce in acid as does the limy sandstone found in the residuum. The landslide debris also contains some clasts of limestone and claystone derived from the Flagstaff Limestone. The nearest outcropping of the North Horn Formation and probable source area of the landslide debris at Aspen Grove is about 200 to $300 \mathrm{~m}$ east-southeast of the head of the Aspen Grove landslide (Baum and Fleming, 1989, plate 1). The landslide debris is 6 to $8 \mathrm{~m}$ thick in the upper half of the landslide and may be thicker in the foot area below the lower road crossing.

\footnotetext{
${ }_{1}^{1}$ South of Aspen Grove, the residuum contains clasts of claystone and white or gray limestone. Fine- to medium-grained, white, limy sandstone clasts occur with the limestone and claystone clasts. Upslope from the upper crossing of the road (fig. 1), clasts of white, limy sandstone and silicified limestone are especially common. In the triangular deposit of residuum north of the modern landslide (fig. 1), white or light-gray limestone occurs with only minor amounts of white, limy sandstone and greenish-gray claystone clasts. In the northeastern corner of the map area (fig. 1), the residuum contains white, fine- to medium-grained, limy sandstone and light-gray claystone with small amounts of limestone.
} 


\section{Distribution of Landslide Debris and Residuum}

$\mathrm{T}$ The distribution of residuum and landslide deposits closely correlates with topographic position at the site (fig. 1). A thin, discontinuous mantle of residuum covers large, north-trending ridges and some minor troughs. Bedrock crops out at few locations, mainly on ridge crests and in road cuts. Landslide debris occupies the main trough through the center, the branch trough in the northeast, and the low-lying, marshy ground in the northwest corner of the area, beyond the limits of the area shown in figure 1 .

\section{Drilling}

Gigure 2 shows the locations of borings drilled by the USGS during the summers of 1984 and 1985. During August 1984, five holes were drilled in the upper part of the landslide with a truck-mounted drill rig formerly operated by the USGS Geotechnical Laboratory, Golden,

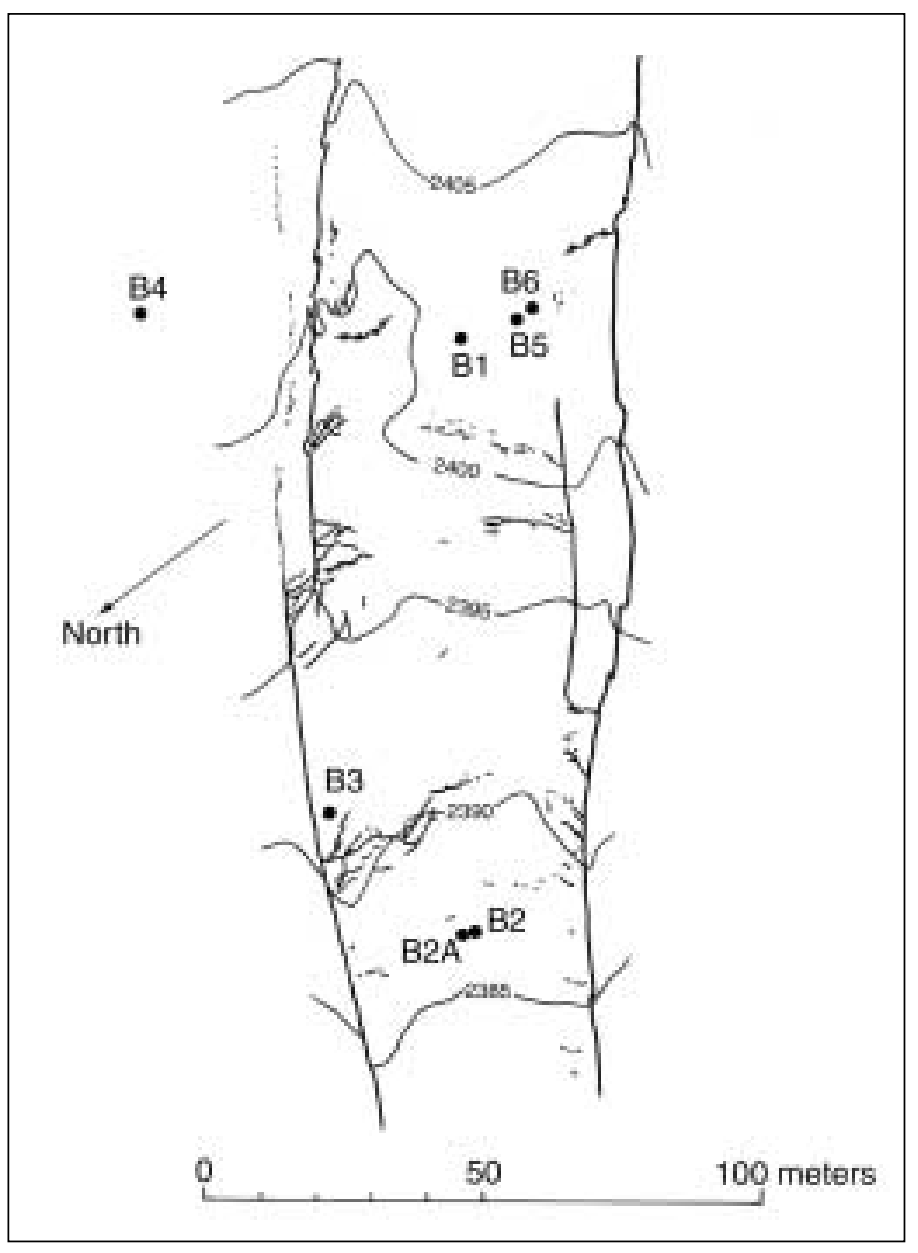

Figure 2. Map showing locations of boreholes in the Aspen Grove landslide. Landslide features and topographic contours based on detailed mapping by Fleming and Johnson (1989).
Colorado (Roger Nichols, Supervisor). One was drilled in ground adjacent to the landslide (borehole B4, figure 2). Another was drilled through the right flank of the landslide (B3), and three others were drilled near midwidth (B1, B2 and B2A). During July 1985, two new holes (B5 and B6) were drilled near B1. Three undisturbed samples were collected near the bottom of borehole B6 for laboratory testing. Logs of the borings (Appendix A) indicate the methods of drilling and sampling used in each hole, the sample intervals, stratigraphic interpretations, instrumentation and methods of backfilling the boreholes.

\section{Geologic interpretation of borehole data}

Gamination of the cuttings and detailed description of cores determined the stratigraphy of the debris in the upper part of the Aspen Grove landslide. The log of one boring (B4, Appendix A) shows the older landslide debris about $30 \mathrm{~m}$ northeast of the modern Aspen Grove landslide. The others (B1, B2, B2A, B3, B5, and B6; Appendix A) show the debris involved in the upper part of the landslide. Details of each profile are different, of course, but three layers can be identified in each profile. From the top downward they are: (1) top soil; 1 to $2 \mathrm{~m}$ of black to dark brown, organic, sandy clay containing sandstone boulders; (2) landslide debris; 4 to $6 \mathrm{~m}$ of brown or yellow-brown, plastic, sandy clay containing sandstone boulders; (3) bedrock of Flagstaff Limestone; green, gray, and tan claystone interbedded with white, cherty limestone. Evidence of a failure surface above or at the top of weathered bedrock is discussed below.

Tube samples collected in borehole B6, in the upper part of the Aspen Grove landslide, were extruded and examined in the laboratory. Drillers pushed a tube sampler inside a hollow-stem auger to obtain nominally continuous, relatively undisturbed samples between depths of $4.57 \mathrm{~m}$ and $6.59 \mathrm{~m}$. Sample recovery totaled $1.51 \mathrm{~m}$, or 75 percent of the total interval sampled. Consequently the depth where samples originated are known only approximately. Several intervals of the tube samples (fig. 3) were thinly laminated, plastic clay, like that shown in figure 4. Alternating intervals were massive plastic clay or silty clay.

Study of the tube sample suggests that the failure zone or slip surface of the landslide passed through the laminated clay at depths of 6.15 or $6.52 \mathrm{~m}$ (fig. 3). A crack and some poorly developed slickensides that dipped about $15^{\circ}$ were observed at a contact between silty clay and laminated clay at a depth of $6.15 \mathrm{~m}$. There was a disturbed zone at the base of the tube sample in greenishgray, waxy shale at a depth of $6.52 \mathrm{~m}$, but much of the disturbance was due to drilling, because the most obvious 


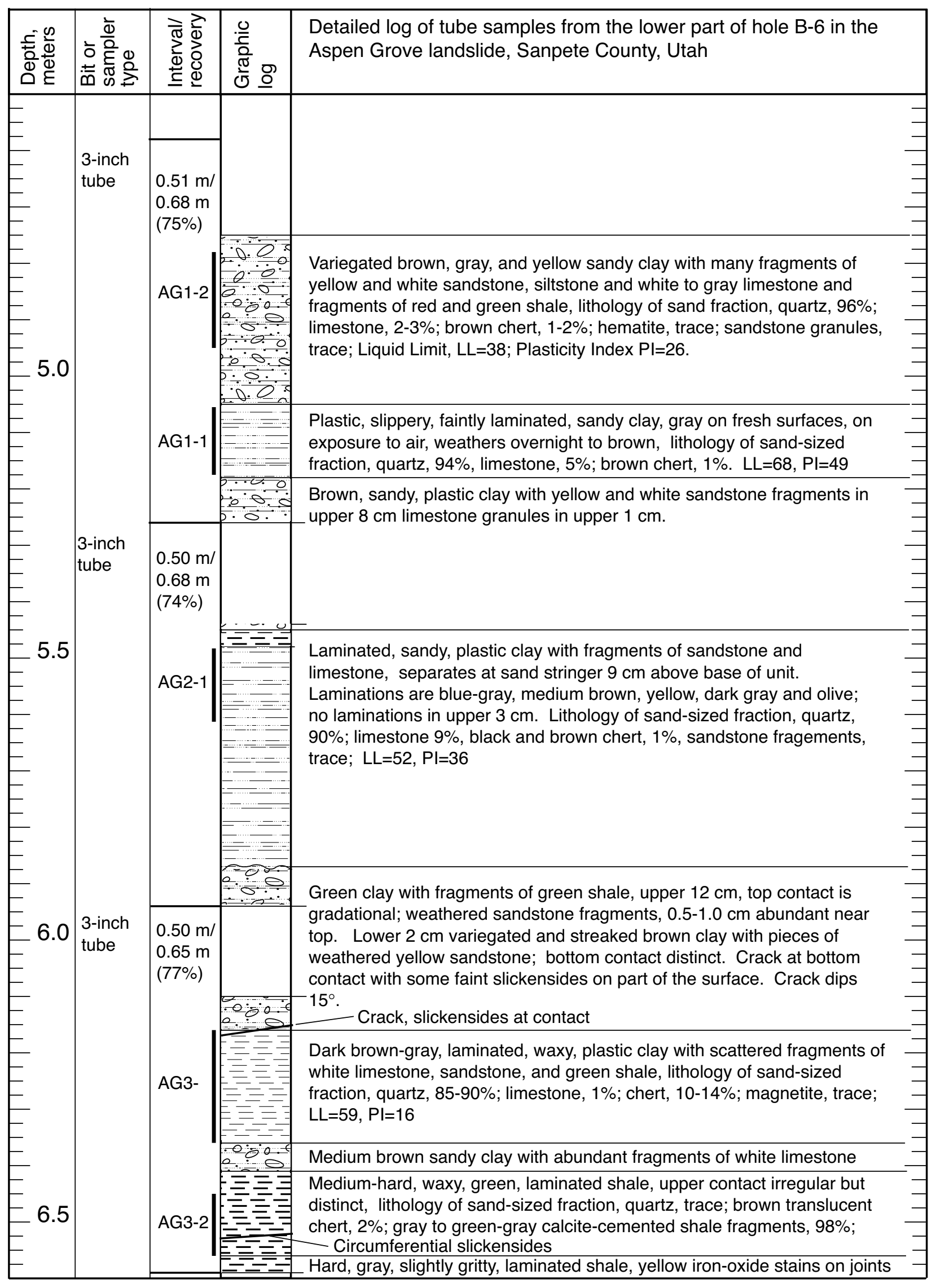

Figure 3. Detailed log of tube samples near the bottom of borehole B-6. The graphic log is drawn as if the material recovered in the tube samples came from the bottom of each interval. 


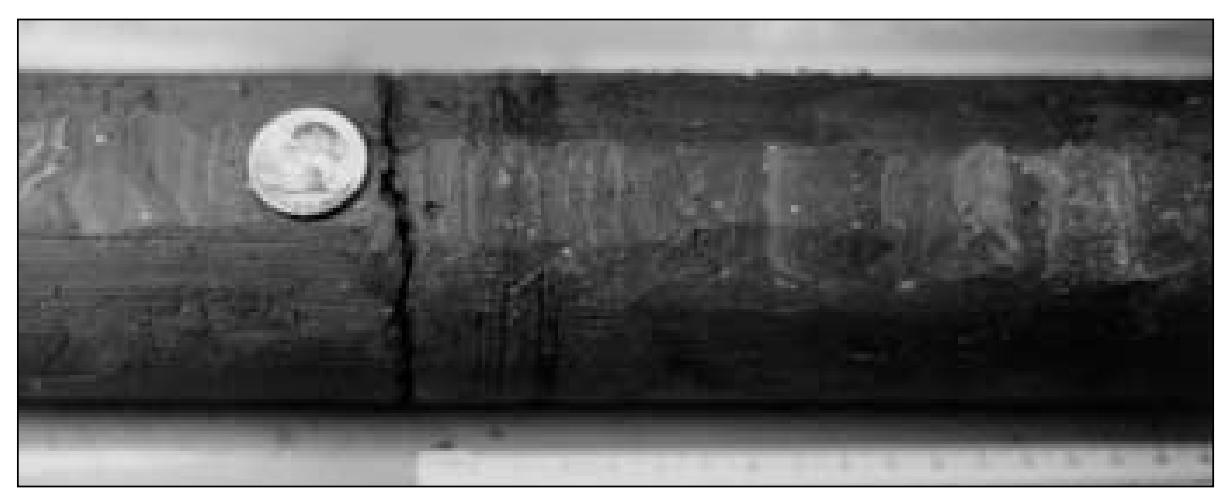

Figure 4. Photograph of tube sample from borehole B-6. Laminated clay from vicinity of the basal shear zone.
D3) were deeper. Cable D5 was not pulled down the hole, and was anchored at a depth of $4.9 \mathrm{~m}$. Monitoring of the cables, therefore, indicated that the failure surface is at a depth between $4.9 \mathrm{~m}$ (D5) and $11 \mathrm{~m}$ (D4). Now, at B1 we also had an observation well of PVC pipe for measuring water levels. It was open to $12.5 \mathrm{~m}$ depth in August 1984. In April 1985, the pipe had been sheared and one could probe it to a depth of only $5.95 \mathrm{~m}$. On this basis, we infer that the failure surface is between 6 and $11 \mathrm{~m}$ deep; we assume that it is $6 \mathrm{~m}$ deep. structures were slickensides with circumferential striations.

\section{Depth to basal slip surface}

$\mathrm{O}$ ur observations determined the thickness of the Aspen Grove landslide in only a few places. Near boreholes B1, B5, and B6, the landslide is about $6 \mathrm{~m}$ deep. At mid width in the landslide near holes B2 and B2A, the depth of the basal slip surface is poorly known, only that it occurs at a depth of between 3.1 and $6.5 \mathrm{~m}$. One to two meters inside the right flank at borehole B3, the failure surface is about $2.5 \mathrm{~m}$ deep2. It is unclear, here, whether the failure surface is the flank fault or the basal shear surface; we suspect it is the flank fault, in which case the average dip of the flank fault would be on the order of 45 to $60^{\circ}$.

Depths to the failure surface in the boreholes were determined by measuring the changes in lengths of cables anchored at various depths in holes B1 and B3, knowing the depths of piezometers that were damaged by landslide movement, or by measuring the depths of observation wells disrupted by the landslide.

For example, at B1 five cables were anchored at different depths, (D1 through D5, Appendix A). Cables D1, D2, D3 and D4 were pulled down the borehole and their length above ground shortened by $2.7 \mathrm{~m}$ between August 1984 and July 1985, indicating that these cables were anchored below the failure surface. Cable D4 was anchored at a depth of $11 \mathrm{~m}$. The others (D1, D2, and

${ }^{2}$ Cables were anchored at various depths in holes B1 and B3 to locate approximately the depth of the failure surface. Cables anchored below the failure surface are pulled down the hole as the landslide moves downslope; consequently, their length above ground shortens. Cables anchored in ground above the failure surface are not pulled down the hole and, thus, their length above ground is unchanged by movement.

\section{Geotechnical Properties}

Samples for determination of standard physical properties were collected from various units within the tube samples taken in borehole B6 in 1985. The samples are identified by the depth in meters near the middle of the sample (table 1) or by sample numbers shown on figure 3 . Two grab samples were also collected from boring B-3 during 1984 (table 2).

Particle-size distributions and Atterberg limits for the samples are given in tables 1 and 2 . The tables show that materials identified as clay or silty clay in the log (fig. 3) indeed are dominantly clay or silty clay. In the bottom 2 $\mathrm{m}$ of borehole B6, the clay content ranges from 44 to 74 percent, the plastic limit (PL) ranges from 12 to 19 percent and the plasticity index (PI) ranges from 26 to 49 percent. A sample of green shale collected about a decimeter above the bedrock has relatively high clay content of 58 percent and a low PI of 28. Microscopic examination of the sand fraction indicates that 95 percent of the sand-sized fraction in the shale sample is actually calcite-cemented claystone fragments. Cementation of the clay particles in the shale might be responsible for the low PI.

The strength of several samples was determined at the USGS Geotechnical Laboratory in Golden, Colorado. An undisturbed sample was tested in order to estimate peak strength and residual strength. Disturbed samples were tested to estimate the residual strength.

\section{Test procedures}

Direct shear test of undisturbed sample.-The tests were done in a direct-shear apparatus under slow, drained conditions. Specimens were cut from tube sample AG3-1 in the interval from 6.15 to $6.35 \mathrm{~m}$ (fig. 3) and trimmed to fit the shear box of the direct shear device $(6.4 \mathrm{~cm}$ in diameter and $2.08 \mathrm{~cm}$ thick). Water content of each specimen before the test was determined from trimmings, and 
Table 1. Physical Properties of Samples from Hole B-6

[Test specimens cut from tube samples representing the depths indicated in the table. Tony Shanahan conducted the tests.]

\begin{tabular}{|c|c|c|c|c|c|c|c|c|}
\hline \multirow{3}{*}{$\begin{array}{l}\text { Sample depth } \\
\text { (meters) }\end{array}$} & \multicolumn{4}{|c|}{ Particle Size Distribution } & \multirow{2}{*}{\multicolumn{3}{|c|}{$\begin{array}{c}\text { Atterberg limits } \\
\text { (water content, percent of weight of solids) }\end{array}$}} & \multirow{3}{*}{$\begin{array}{l}\text { Grain density } \\
\left(\mathrm{g} / \mathrm{cm}^{3}\right)\end{array}$} \\
\hline & Gravel & Sand & Silt & Clay & & & & \\
\hline & $>4.76 \mathrm{~mm}$ & $\begin{array}{c}\begin{array}{c}4.76- \\
\mathrm{mm}\end{array} \\
\mathrm{mm}\end{array}$ & $\begin{array}{c}0.075-0.005 \\
\mathrm{~mm}\end{array}$ & $<0.005 \mathrm{~mm}$ & LL & PL & PI & \\
\hline 4.8 & 0 & 27 & 29 & 44 & 38 & 12 & 26 & 2.76 \\
\hline 5.1 & 1 & 11 & 29 & 59 & 68 & 19 & 49 & 2.75 \\
\hline 5.6 & 1 & 14 & 31 & 54 & 52 & 16 & 36 & 2.81 \\
\hline 6.3 & 2 & 6 & 18 & 74 & 59 & 16 & 43 & 2.68 \\
\hline 6.5 & 0 & 17 & 25 & 58 & 46 & 18 & 28 & 2.76 \\
\hline
\end{tabular}

Table 2. Physical Properties of Samples from Hole B-3

[Test specimens were grab samples of cuttings collected when the auger bit was at the depth indicated. Tony Shanahan conducted the tests]

\begin{tabular}{|c|c|c|c|c|c|c|c|c|}
\hline \multirow{3}{*}{$\begin{array}{l}\text { Sample depth } \\
\quad \text { (meters) }\end{array}$} & \multicolumn{4}{|c|}{ Particle Size Distribution } & \multirow{2}{*}{\multicolumn{3}{|c|}{$\begin{array}{c}\text { Atterberg limits } \\
\text { (water content, percent of weight of solids) }\end{array}$}} & \multirow{3}{*}{$\begin{array}{c}\text { Grain density } \\
\left(\mathrm{g} / \mathrm{cm}^{3}\right)\end{array}$} \\
\hline & Gravel & Sand & Silt & Clay & & & & \\
\hline & $>4.76 \mathrm{~mm}$ & $\begin{array}{c}4.76-0.075 \\
\mathrm{~mm}\end{array}$ & $\begin{array}{l}0.075-0.005 \\
\mathrm{~mm}\end{array}$ & $<0.005 \mathrm{~mm}$ & $\mathrm{LL}$ & PL & PI & \\
\hline 7.3 & 0 & 6 & 33 & 61 & 61 & 16 & 45 & 2.72 \\
\hline 11.3 & 0 & 14 & 16 & 70 & 41 & 15 & 26 & 2.72 \\
\hline
\end{tabular}

Table 3. Summary results of direct shear tests

[George S. Erickson and Anthony Shanahan performed the tests. Sample type, "I" denotes intact, "R" denotes remolded. Sample ID appears on laboratory plots of stress and displacement. Water content reported as weight percent of solids. Peak strength of remolded samples not representative of peak strength of intact material]

\begin{tabular}{lcrrrrrrrr}
\hline $\begin{array}{c}\text { Borehole/ } \\
\text { Sample ID }\end{array}$ & $\begin{array}{c}\text { Sample } \\
\text { Type }\end{array}$ & $\begin{array}{c}\text { Depth } \\
(\mathrm{m})\end{array}$ & $\begin{array}{c}\text { Normal } \\
\text { Stress, } \\
\left(\mathrm{kN} / \mathrm{m}^{2}\right)\end{array}$ & $\begin{array}{c}\text { Initial } \\
\text { water } \\
\text { content }\end{array}$ & $\begin{array}{c}\text { Final } \\
\text { water } \\
\text { content }\end{array}$ & $\begin{array}{c}\text { Rate } \\
(\mathrm{mm} / \mathrm{min})\end{array}$ & $\begin{array}{c}\text { Peak } \\
\text { strength } \\
\left(\mathrm{kN} / \mathrm{m}^{2}\right)\end{array}$ & $\begin{array}{c}\text { Displacement } \\
\text { at peak } \\
(\mathrm{mm})\end{array}$ & $\begin{array}{c}\text { Residual } \\
\text { strength } \\
\left(\mathrm{kN} / \mathrm{m}^{2}\right)\end{array}$ \\
\hline B-6/ AG3-1 & I & 6.3 & 34.5 & 19.0 & 25.7 & 0.0240 & 42.4 & 1.0 & 21.5 \\
B-6/ AG3-1 & I & 6.3 & 137.9 & 19.2 & 23.9 & 0.0240 & 76.7 & 1.2 & 43.2 \\
B-6/ AG3-1 & I & 6.3 & 413.8 & 20.7 & 23.2 & 0.0240 & 122.4 & 5.4 & 116.7 \\
\hline B-3/ DH4-1 & R & 7.3 & 47.9 & 15.7 & 26.9 & 0.0048 & 28.0 & 0.9 & 19.3 \\
B-3/ DH4-1 & R & 7.3 & 382.9 & 14.2 & 22.4 & 0.0048 & 116.8 & 4.2 & 104.5 \\
B-3/ DH4-1 & R & 7.3 & 750.3 & -- & -- & 0.0048 & 216.8 & 6.2 & 208.9 \\
\hline B-3/ DH4-2 & R & 11.3 & 47.9 & 13.0 & 22.0 & 0.0048 & 30.4 & 3.1 & 26.9 \\
B-3/ DH4-2 & R & 11.3 & 382.9 & 13.8 & 17.7 & 0.0048 & 176.5 & 7.0 & 174.8 \\
B-3/ DH4-2 & R & 11.3 & 765.8 & 12.8 & 18.5 & 0.0048 & 326.6 & 7.6 & 325.4
\end{tabular}

water content after the test was determined from a piece of the specimen. Each specimen was placed in the shear box of the direct shear apparatus and consolidated under a normal stress (table 3). Each specimen was then sheared at a constant rate (table 3 ) until displacement totaled $9 \mathrm{~mm}$. Three separate specimens were tested at different normal loads. The stress-displacement diagrams are shown in Appendix B.

Direct shear test of disturbed, remolded samples.-The tests were done in a direct-shear apparatus under slow, drained conditions. Specimens were remolded from material passing a number 10 sieve (material finer than $2 \mathrm{~mm}$ ) and tamped into the $6.4 \mathrm{~cm}$ diameter shear box. The remaining test procedure was the same as for the undisturbed sample.

Torsional shear test of disturbed, remolded samples.The tests were done in a Bromhead ring-shear apparatus under slow, drained conditions. Representative samples were remolded from the material passing a number 40 sieve (finer than $0.425 \mathrm{~mm}$ ) after the Atterberg limits 
tests were completed. The samples were consolidated and later sheared under a normal load of either $34.5,137.9$, or $344.8 \mathrm{kN} / \mathrm{m}^{2}$ (5, 20 and $\left.50 \mathrm{lb} / \mathrm{in} .^{2}\right)$. After consolidation, the samples were rotated two revolutions to develop a shear plane. The samples were then rotated at a rate of $0.267 \mathrm{~mm} /$ minute for about $250 \mathrm{~mm}$; the rate was then doubled and shear continued for about four hours $(\sim 130$ $\mathrm{mm})$. Finally the rate was reduced by a factor of five to finish the test for a total displacement of $400 \mathrm{~mm}$. The ring shear sample is only $5 \mathrm{~mm}$ thick and drained at the top and bottom; thus, drained tests proceed at higher rates than in the direct shear apparatus. Table 4 summarizes results of the individual tests.

\section{Shear Strength}

$\mathrm{T}$ able 5 summarizes shear-strength parameters of material from the Aspen Grove landslide. The land-

Table 4. Summary results of torsional shear tests

[George S. Erickson performed the tests. Water content reported as weight percent of solids. Rate is average value at middle of sample. After $250 \mathrm{~mm}$ of displacment, rate was doubled; after an additional $130 \mathrm{~mm}$ of displacement, the rate was reduced by a factor of 5]

\begin{tabular}{rrrrrrr}
\hline $\begin{array}{c}\text { Borehole/ } \\
\text { Sample ID }\end{array}$ & $\begin{array}{c}\text { Depth } \\
(\mathrm{m})\end{array}$ & $\begin{array}{c}\text { Normal } \\
\text { Stress, } \\
\left(\mathrm{kN} / \mathrm{m}^{2}\right)\end{array}$ & $\begin{array}{c}\text { Initial } \\
\text { water } \\
\text { content }\end{array}$ & $\begin{array}{c}\text { Final } \\
\text { water } \\
\text { content }\end{array}$ & $\begin{array}{c}\text { Rate } \\
(\mathrm{mm} / \mathrm{min})\end{array}$ & $\begin{array}{c}\text { Residual } \\
\text { strength } \\
\left(\mathrm{kN} / \mathrm{m}^{2}\right)\end{array}$ \\
\hline B-6/ AG1-2 & 4.8 & 34.5 & 27.4 & 28.1 & 0.267 & 18.4 \\
B-6/ AG1-2 & 4.8 & 137.9 & 26.7 & 23.8 & 0.267 & 65.4 \\
B-6/ AG1-2 & 4.8 & 344.8 & 26.7 & 23.2 & 0.267 & 108.8 \\
\hline B-6/ AG1-1 & 5.1 & 34.5 & 57.5 & 50.4 & 0.267 & 13.5 \\
B-6/ AG1-1 & 5.1 & 137.9 & 56.1 & 44.2 & 0.267 & 23.7 \\
B-6/ AG1-1 & 5.1 & 344.8 & 55.2 & 44.2 & 0.267 & 43.6 \\
\hline B-6/ AG3-1 & 6.3 & 34.5 & 42.5 & 38.7 & 0.267 & 8.6 \\
B-6/ AG3-1 & 6.3 & 137.9 & 42.7 & 39.7 & 0.267 & 19.2 \\
B-6/ AG3-1 & 6.3 & 342.9 & 43.0 & 41.6 & 0.267 & 40.2
\end{tabular}

Table 5. Summary of shear strength parameters for effective stress from drained direct shear and ring shear tests

[DS denotes direct shear test, RS denotes torsional ring shear test]

\begin{tabular}{|c|c|c|c|c|c|c|}
\hline \multirow[b]{2}{*}{$\begin{array}{c}\text { Borehole/ } \\
\text { Sample ID }\end{array}$} & \multirow[b]{2}{*}{$\begin{array}{l}\text { Test } \\
\text { Type }\end{array}$} & \multirow[b]{2}{*}{$\begin{array}{l}\text { Depth } \\
\text { (m) }\end{array}$} & \multicolumn{2}{|c|}{ Peak Strength } & \multicolumn{2}{|c|}{ Residual Strength } \\
\hline & & & $\begin{array}{l}\text { Angle of } \\
\text { internal } \\
\text { friction } \\
\text { (degrees) }\end{array}$ & $\begin{array}{l}\text { Cohesion } \\
\left(\mathrm{kN} / \mathrm{m}^{2}\right)\end{array}$ & $\begin{array}{l}\text { Angle of } \\
\text { internal } \\
\text { friction } \\
\text { (degrees) }\end{array}$ & $\begin{array}{c}\text { Cohesion } \\
\left(\mathrm{kN} / \mathrm{m}^{2}\right)\end{array}$ \\
\hline B-6/ AG3-1 & $\mathrm{DS}$ & 6.3 & 11.4 & 41.1 & 14.3 & 10.8 \\
\hline B-6/ AG3-1 & $\mathrm{RS}$ & 6.3 & -- & -- & 5.8 & 5.1 \\
\hline B-6/ AG1-1 & $\mathrm{RS}$ & 4.8 & -- & -- & 5.5 & 10.2 \\
\hline B-6/ AG1-2 & $\mathrm{RS}$ & 5.1 & -- & -- & 15.6 & 16.0 \\
\hline B-3/ DH4-1 & DS & 7.3 & -- & -- & 15.1 & 4.5 \\
\hline B-3/ DH4-2 & DS & 11.3 & -- & -- & 22.6 & 10.0 \\
\hline
\end{tabular}

slide was a reactivation of old landslide deposits, therefore, testing focused on determining residual shear strength because it is relevant to reactivation. The angle of residual friction, for effective stress, ranged from $5^{\circ}$ to $23^{\circ}$, and residual cohesion, also for effective stress, ranged from 5 to $16 \mathrm{kN} / \mathrm{m}^{2}$ (table 5). The landslide material is heterogeneous and representative values for the basal shear zone probably lie somewhere inside the observed ranges.

Test results for a sample from the basal shear zone of the landslide are of particular interest. The strengths of the specimens are plotted as a function of normal stress in figure 5. The peak strength defines a segmented failure envelope. The intercept is about $31 \mathrm{kN} / \mathrm{m}^{2}$ and the segment defining peak strengths at lower normal stress slopes about $18^{\circ}$. The segment defining peak strengths at higher normal stresses slopes about $9^{\circ}$.

Upper- and lower-bound estimates of the residual strength are also shown in figure 5 . The upper-bound estimate uses the strength at the end of each direct-shear test. The upper-bound failure envelope has an intercept of $10.8 \mathrm{kN} / \mathrm{m}^{2}$ and slopes $14.3^{\circ}$. The lower-bound estimate uses the residual strength determined for the specimen tested under a normal stress of $414 \mathrm{kN} / \mathrm{m}^{2}$, and projects through the origin. Slopes of the stress-displacement diagrams (Appendix B) indicate that the specimen tested under a normal stress of $414 \mathrm{kN} / \mathrm{m}^{2}$ was the only one of the three that attained its residual strength after $9 \mathrm{~mm}$ of shearing. The lower-bound estimate has an intercept of $0 \mathrm{kN} / \mathrm{m}^{2}$ and slopes $15.8^{\circ}$. A torsional shear test on material from the same interval had residual-strength parameters of $5^{\circ}$ and $5.2 \mathrm{kN} / \mathrm{m}^{2}$. Removal of particles larger than 0.425 $\mathrm{mm}$ from the torsional shear test specimens may have reduced the strength slightly relative to the total sample; however, the coarse particles accounted for only about 2 percent of the total.

\section{Surface and Subsurface Water Observations \\ Snow meltwater infiltrating at the sur- face of the landslide was almost cer- tainly the main source of water in the landslide. When we visited the landslide in May 1984, snow was still melting on}




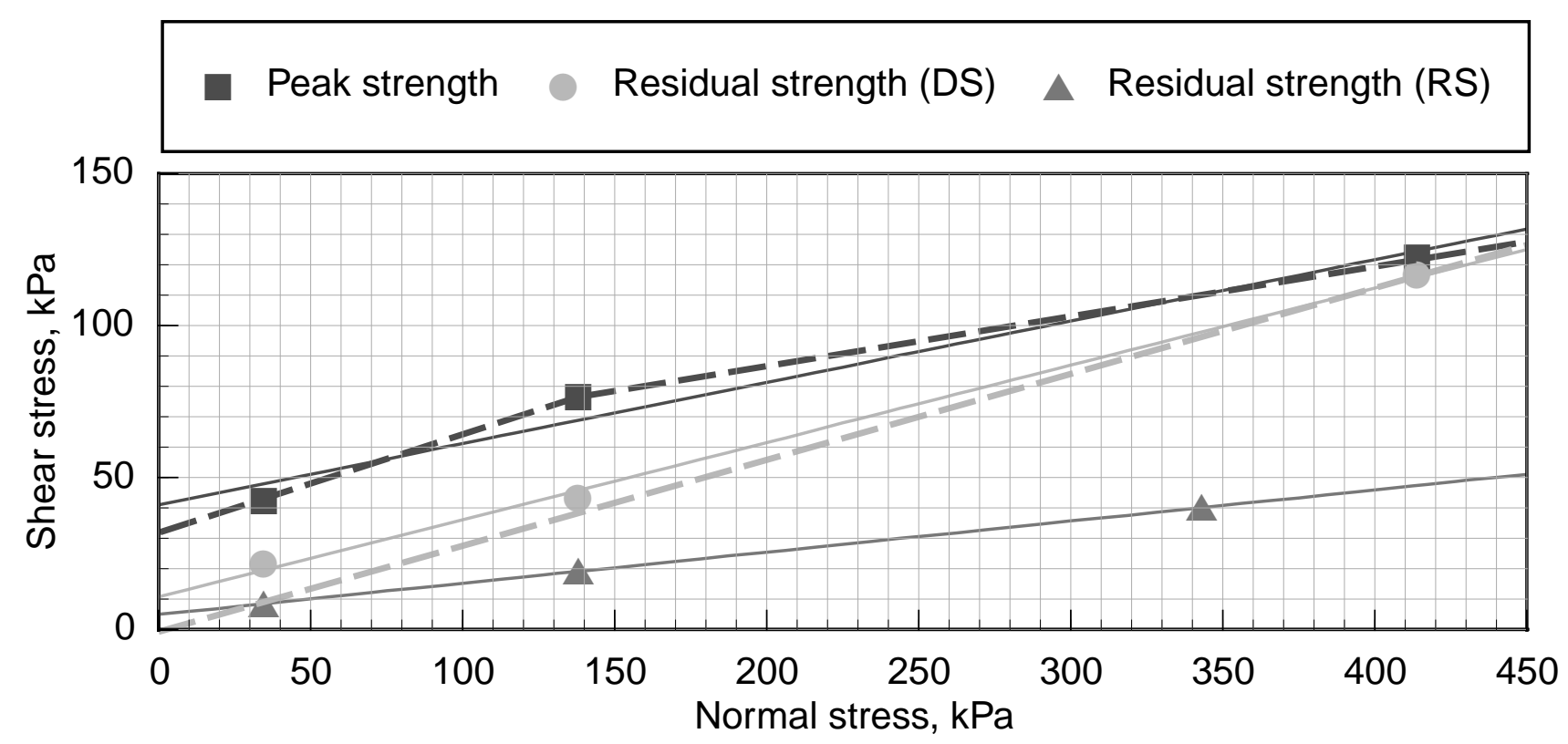

Figure 5. Failure envelopes for sample AG3-1 from about $6.3 \mathrm{~m}$ depth in borehole B-6. Peak shear strength, dashed black line represents segmented strength envelope; solid black line represents best fit straight-line envelope. Residual strength by direct shear (DS), dashed light-gray line represents lowerbound estimate through the origin and the strength at the highest normal load; solid light-gray line represents best fit straight line envelope and upper bound estimate of the resiudal strength. Residual strength by torsional shear (RS) solid gray line represents best fit straight-line envelope.

the surface of the landslide. Meltwater flowed everywhere across the surface of the landslide, in numerous rivulets. Shallow holes, about $1 \mathrm{~m}$ deep, dug into the internal toe and at the lower road crossing, to emplace pressure cells, quickly filled with water flowing from the walls of the holes. Cracks and hollows contained ponded water. The trough-like topography on the surface of the landslide channelizes the meltwater from the head to the foot. Surface channels drain away from the landslide only in the area of the old foot. Even there, channels bring the water back onto the sliding ground beyond the internal toe (figure 1).

Timing of the landslide activity was roughly synchronous with the presence of surface water on the landslide. The beginning of movement coincided approximately with the spring thaw in 1984, 1985 and 1986. The end of movement coincided approximately with the drying up of ponds on the surface of the landslide.

Water-level measurements during parts of 1985 and 1986 in six boreholes, B1 through B6, are shown in Tables 6 and 7. Water levels were measured directly in boreholes B1, B2 and B3, and water levels were calculated from piezometric measurements made in boreholes B4, B5 and B6. We have indicated the water levels in terms of the height of water above the sensor or base of the open-tube piezometer. Some of the vibrating-wire piezometers were destroyed by movement of the land- slide early in the spring of 1984 and did not provide any useful data.

The measurements show that, at three locations within the upper part of the landslide, between B-1 and B-2, the water level was always within $3 \mathrm{~m}$ of the ground surface during April through August 1985 and during February through September 1986. The best record exists for B1, where water level fell $1.2 \mathrm{~m}$ from a maximum height of about $0.3 \mathrm{~m}$ below the ground surface during May to about $1.5 \mathrm{~m}$ below the ground surface when movement stopped in 1985. According to the scant data, the water level was at a depth of about $1 \mathrm{~m}$ when movement began in 1986. Again, the water level appears to have reached a maximum during May (tables 6 and 7). In contrast, the water level in the one borehole in stable ground outside the landslide, B4 (table 7) was always low, at depths greater than $3 \mathrm{~m}$ below the ground surface. Water levels ranged from 3 to $5 \mathrm{~m}$ below the ground surface during the period of measurement (table 7). 
Table 6. Height of water column (pressure head) observed at open-tube piezometers

\begin{tabular}{|c|c|c|c|}
\hline Boring & B1 & B2A & B3 \\
\hline $\begin{array}{l}\text { Depth of } \\
\text { piezometer } \\
\text { (meters) }\end{array}$ & 5.96 & 3.46 & 12.48 \\
\hline Date & $\begin{array}{l}\text { Pressure head } \\
\text { (meters) }\end{array}$ & $\begin{array}{c}\text { Pressure head } \\
\text { (meters) }\end{array}$ & $\begin{array}{c}\text { Pressure head } \\
\text { (meters) }\end{array}$ \\
\hline $4 / 21 / 85$ & 3.369 & 3.46 & 1.72 \\
\hline $4 / 24 / 85$ & 3.7 & -- & 1.66 \\
\hline $4 / 26 / 85$ & 4.96 & -- & 1.91 \\
\hline $4 / 28 / 85$ & 5.312 & -- & 1.67 \\
\hline $4 / 28 / 85$ & 5.325 & -- & -- \\
\hline $4 / 29 / 85$ & 5.96 & -- & 1.70 \\
\hline $4 / 30 / 85$ & 5.312 & -- & 1.70 \\
\hline $5 / 1 / 85$ & 5.401 & 3.409 & 1.70 \\
\hline $5 / 5 / 85$ & 5.646 & 2.492 & -- \\
\hline $5 / 15 / 85$ & 5.506 & 3.46 & 1.69 \\
\hline $5 / 18 / 85$ & 5.417 & 3.46 & 1.43 \\
\hline $5 / 24 / 85$ & 5.319 & 3.46 & 1.22 \\
\hline $5 / 31 / 85$ & 5.315 & 3.158 & 1.00 \\
\hline $6 / 4 / 85$ & 5.246 & 3.133 & 0.94 \\
\hline $6 / 14 / 85$ & 5.08 & 2.79 & 0.77 \\
\hline $7 / 2 / 85$ & 4.92 & 2.39 & 0.41 \\
\hline $7 / 8 / 85$ & 4.7 & 2.12 & 0.42 \\
\hline $7 / 11 / 85$ & 4.58 & 1.98 & 0.32 \\
\hline $7 / 15 / 85$ & 4.48 & 1.81 & 0.27 \\
\hline $7 / 18 / 85$ & 4.41 & 1.66 & 0.23 \\
\hline $7 / 22 / 85$ & 4.35 & 1.59 & 0.19 \\
\hline $7 / 26 / 85$ & 4.32 & 1.48 & 0.12 \\
\hline $7 / 29 / 85$ & 4.27 & 1.4 & 0.07 \\
\hline $8 / 1 / 85$ & 4.24 & 1.31 & 0.03 \\
\hline $4 / 18 / 86$ & -- & 3.33 & 1.06 \\
\hline $5 / 28 / 86$ & 5.265 & 3.12 & 0.83 \\
\hline $5 / 31 / 86$ & 5.2 & 3.03 & 0.79 \\
\hline $9 / 9 / 86$ & 3.63 & 0.53 & 0.00 \\
\hline
\end{tabular}

${ }^{1}$ Depth varied through time as the landslide moved over a bump
in the slip surface. Initially the tube sheared at depth of $2.48 \mathrm{~m}$.
As the slide moved, the tube gradually pushed out of the ground.
By September 1986, the upper $1.16 \mathrm{~m}$ of the tube protruded from
the ground and the base of the tube was $1.32 \mathrm{~m}$ below the ground surface. 
Table 7. Pressure head observed using vibriating-wire piezometers. [Piezometers shown on logs but not listed in table stopped working before the 1985 field season. Piezometers were by Slope Indicator Co., model number 52605211, 150 psi pressure range.]

\begin{tabular}{|c|c|c|c|c|c|}
\hline Boring & B2 & B4 & B4 & B5 & B6 \\
\hline $\begin{array}{l}\text { Depth of } \\
\text { sensor, } \\
\text { meters }\end{array}$ & 17.28 & 5.03 & 6.71 & 6.10 & 6.48 \\
\hline Date & $\begin{array}{c}\text { Pressure head } \\
\text { (meters) }\end{array}$ & $\begin{array}{c}\text { Pressure head } \\
\text { (meters) }\end{array}$ & $\begin{array}{c}\text { Pressure head } \\
\text { (meters) }\end{array}$ & $\begin{array}{c}\text { Pressure head } \\
\text { (meters) }\end{array}$ & $\begin{array}{c}\text { Pressure head } \\
\text { (meters) }\end{array}$ \\
\hline $4 / 21 / 85$ & 0.45 & 1.87 & 2.36 & -- & -- \\
\hline $4 / 23 / 85$ & 0.39 & 1.75 & 2.36 & -- & -- \\
\hline $4 / 24 / 85$ & 0.45 & 1.87 & 2.42 & -- & -- \\
\hline $6 / 24 / 85$ & -- & 0.99 & 2.03 & -- & -- \\
\hline $6 / 27 / 85$ & -- & 0.66 & 1.72 & -- & -- \\
\hline $6 / 27 / 85$ & -- & 0.81 & 1.93 & -- & -- \\
\hline $7 / 2 / 85$ & -- & 0.60 & 1.75 & 5.09 & 5.36 \\
\hline $7 / 3 / 85$ & -- & -- & -- & 7.70 & 6.57 \\
\hline $7 / 5 / 85$ & -- & 0.54 & 1.75 & 7.88 & 6.27 \\
\hline $7 / 8 / 85$ & -- & 0.51 & 1.69 & 8.00 & 6.34 \\
\hline $7 / 11 / 85$ & -- & 0.48 & 1.69 & 8.00 & 6.21 \\
\hline $7 / 15 / 85$ & -- & 0.42 & 1.69 & 7.94 & 6.08 \\
\hline $7 / 18 / 85$ & -- & 0.30 & 1.60 & 7.76 & 5.95 \\
\hline $7 / 22 / 85$ & -- & 0.24 & 1.63 & 7.73 & 5.95 \\
\hline $7 / 23 / 85$ & -- & 0.27 & 1.63 & 7.70 & 5.95 \\
\hline $7 / 26 / 85$ & -- & 0.12 & 1.45 & 7.46 & 5.81 \\
\hline $7 / 29 / 85$ & -- & 0.06 & 1.45 & 7.28 & 5.75 \\
\hline $8 / 1 / 85$ & -- & 0.00 & 1.45 & 7.09 & 5.68 \\
\hline $2 / 12 / 86$ & -- & -0.42 & 1.63 & 5.28 & 5.46 \\
\hline $3 / 14 / 86$ & -- & -0.72 & 1.33 & 5.94 & 5.10 \\
\hline $4 / 18 / 86$ & -- & -0.48 & 2.12 & 6.06 & 4.90 \\
\hline $5 / 28 / 86$ & -- & 1.45 & 3.33 & 6.25 & -- \\
\hline $5 / 31 / 86$ & -- & 1.42 & 3.20 & 6.18 & -- \\
\hline $9 / 9 / 86$ & -- & -0.66 & -- & 4.37 & -- \\
\hline
\end{tabular}

\section{References Cited}

Baum, R.L., 1988, The Aspen Grove landslide, Ephraim Canyon, central Utah: Cincinnati, Ohio, The University of Cincinnati, unpublished Ph.D. dissertation, 363 p.

Baum, R.L., Johnson, A.M., and Fleming, R.W., 1988, Measurement of slope deformation using quadrilaterals, chap. B of Landslide processes in Utah-Observation and theory: U.S. Geological Survey Bulletin 1842, p. B1-B23.

Baum, R.L., and Fleming, R.W., 1989, Landslides and debris flows in Ephraim Canyon, central Utah, chap. $\mathrm{C}$ of Landslide processes in Utah-Observation and theory: U.S. Geological Survey Bulletin 1842, p. C1-C12, 1 oversize plate.

Baum, R.L., Fleming, R.W., and Johnson, A.M., 1993 [1994], Kinematics of the Aspen Grove landslide, Ephraim Canyon, central Utah, chap. F of Landslide processes in UtahObservation and theory: U.S. Geological Survey Bulletin 1842, p. F1-F34.
Baum, R.L., and Reid, M.E., 2000, Groundwater isolation by low-permeability clays in landslide shear zones, in Bromhead, E., Dixon, N, and Ibsen, M., eds., Landslides in Research, Theory and Practice, Proceedings of the 8th International Symposium on Landslides: London, Thomas Telford p. 139-144.

Fleming, R.W., and Johnson, A.M., 1989, Structures associated with strike-slip faults that bound landslide elements: Engineering Geology, v. 27, p. 39-114.

Stanley, K.O., and Collinson, J.W., 1979, Depositional history of Paleocene-lower Eocene Flagstaff Limestone and coeval rocks, central Utah: American Association of Petroleum Geologists Bulletin, v. 63, no. 3, p. 311-323. 


\section{Appendix A. Borehole logs}

B-1

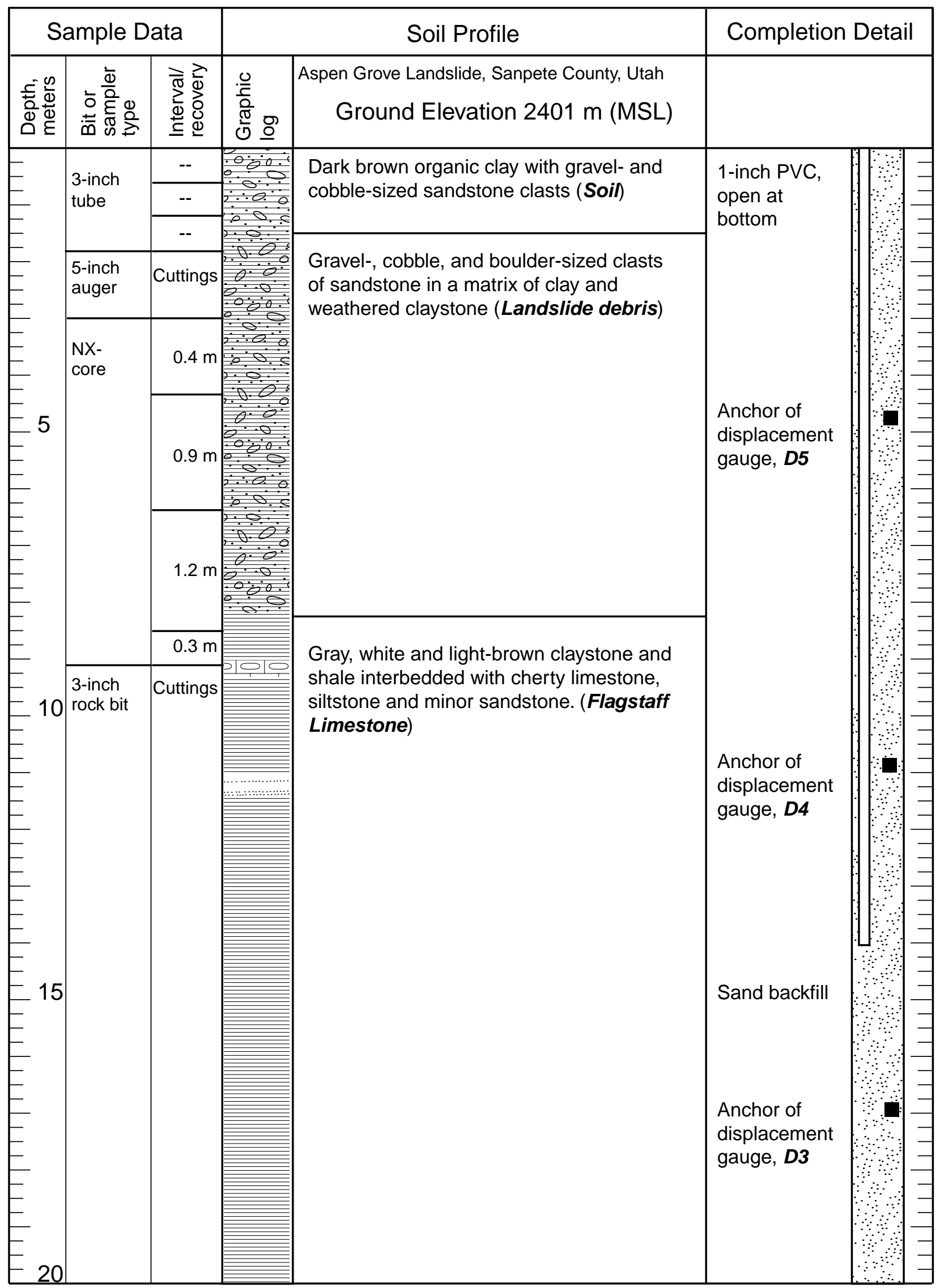




\section{Appendix A. Borehole logs-continued}

B-1 (continued)

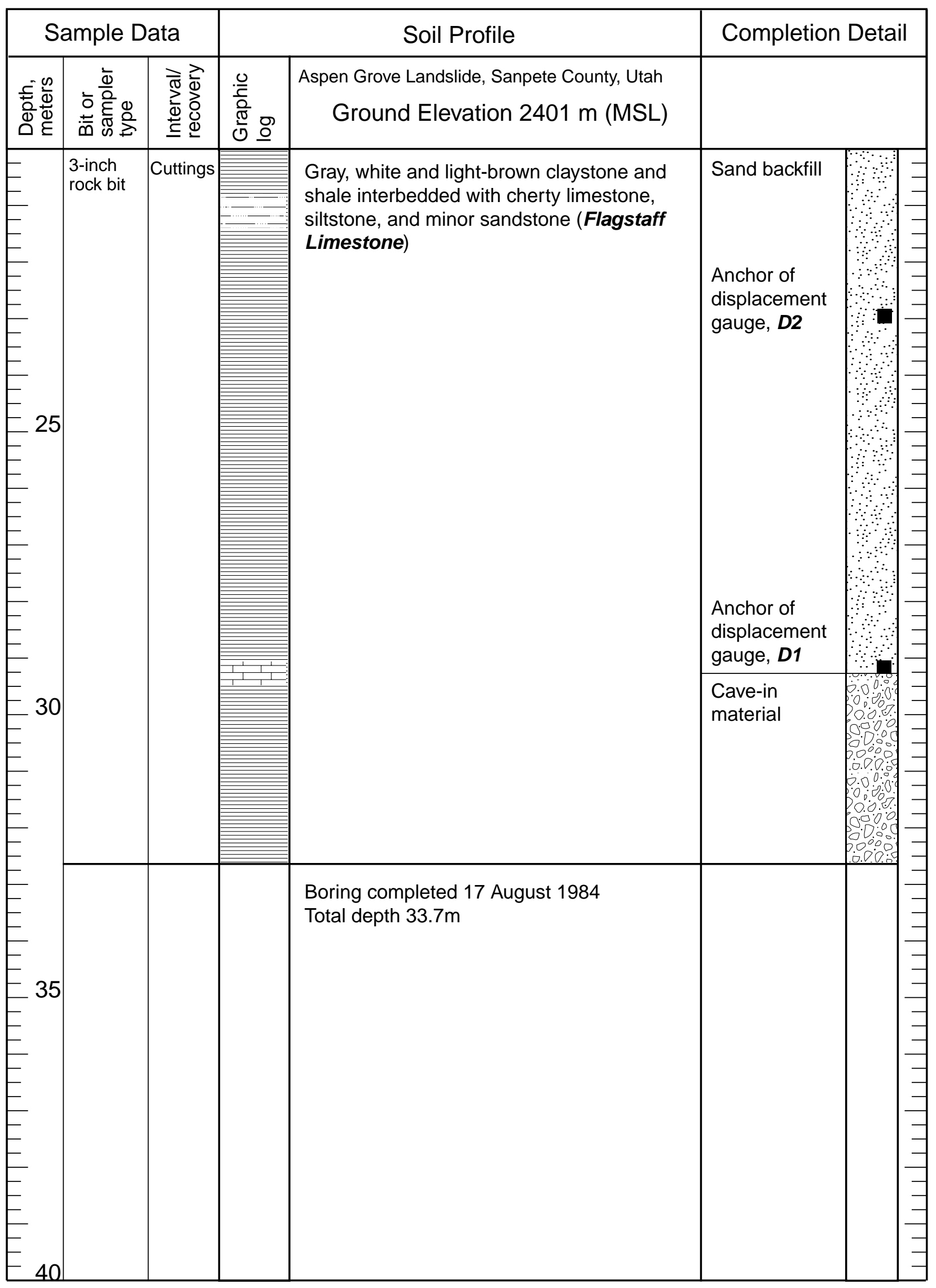




\section{Appendix A. Borehole logs-continued}

B-2

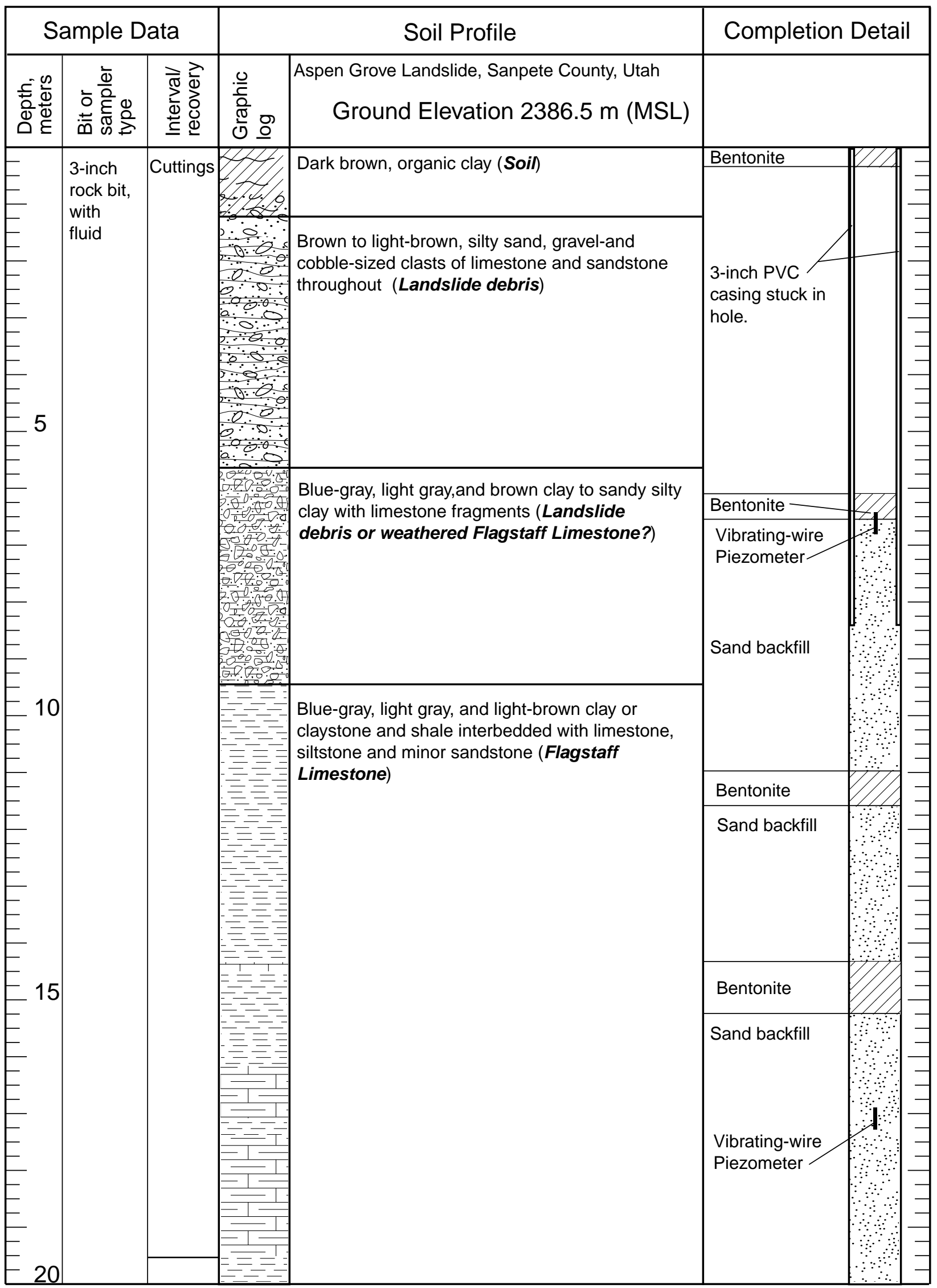




\section{Appendix A. Borehole logs-continued}

B-2 (continued)

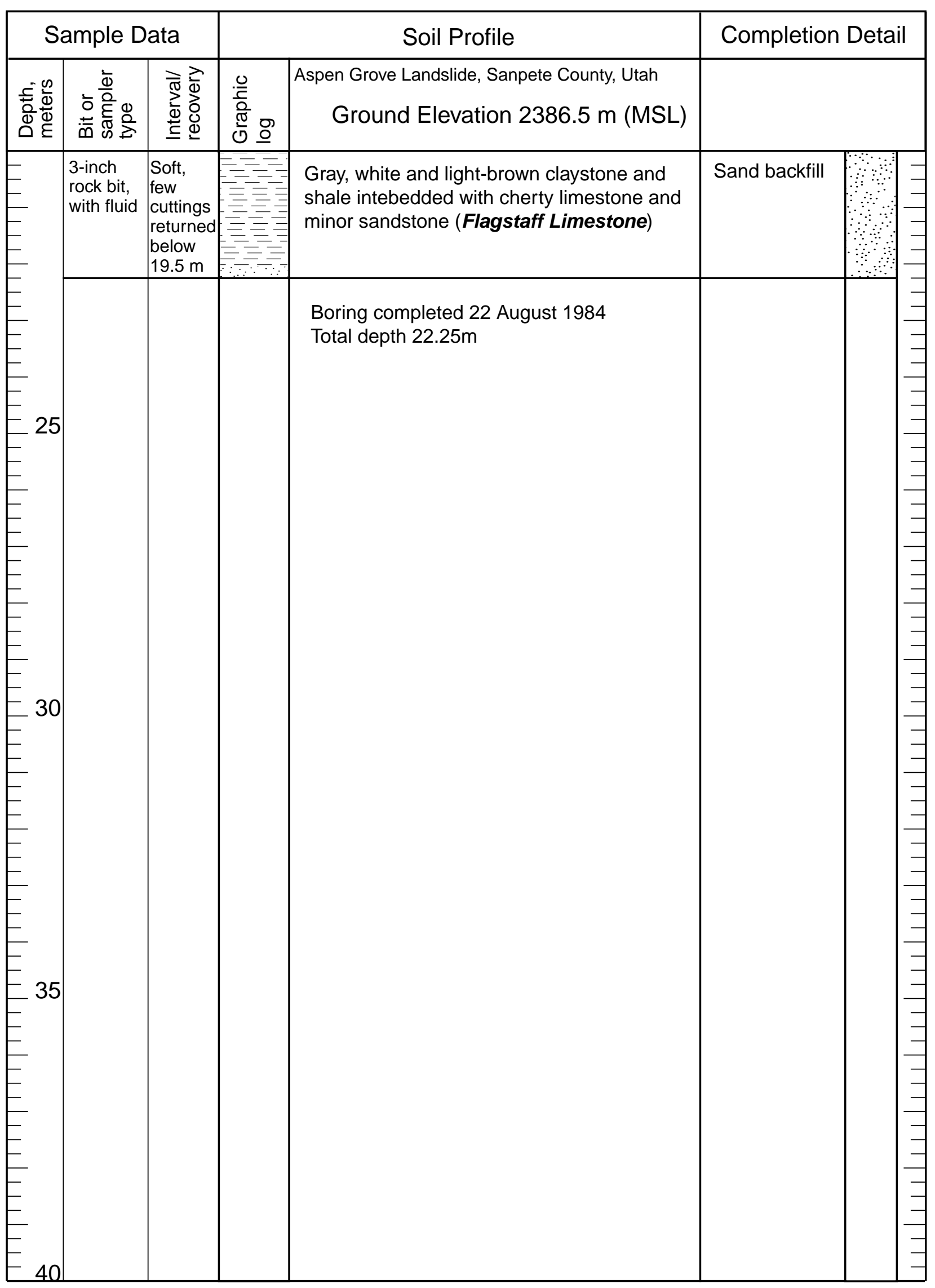




\section{Appendix A. Borehole logs-continued}

B-2A

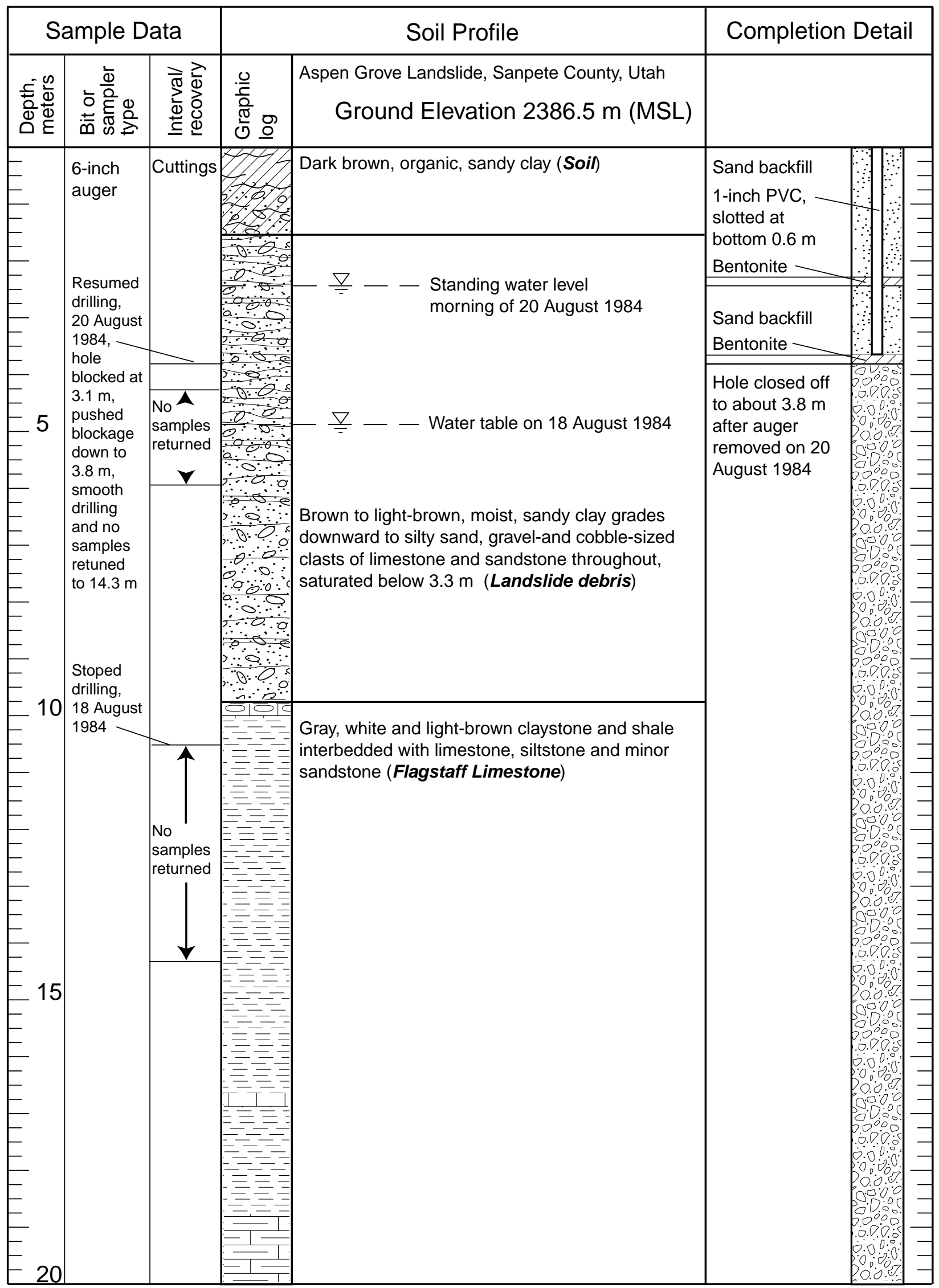




\section{Appendix A. Borehole logs-continued}

B-2A (continued)

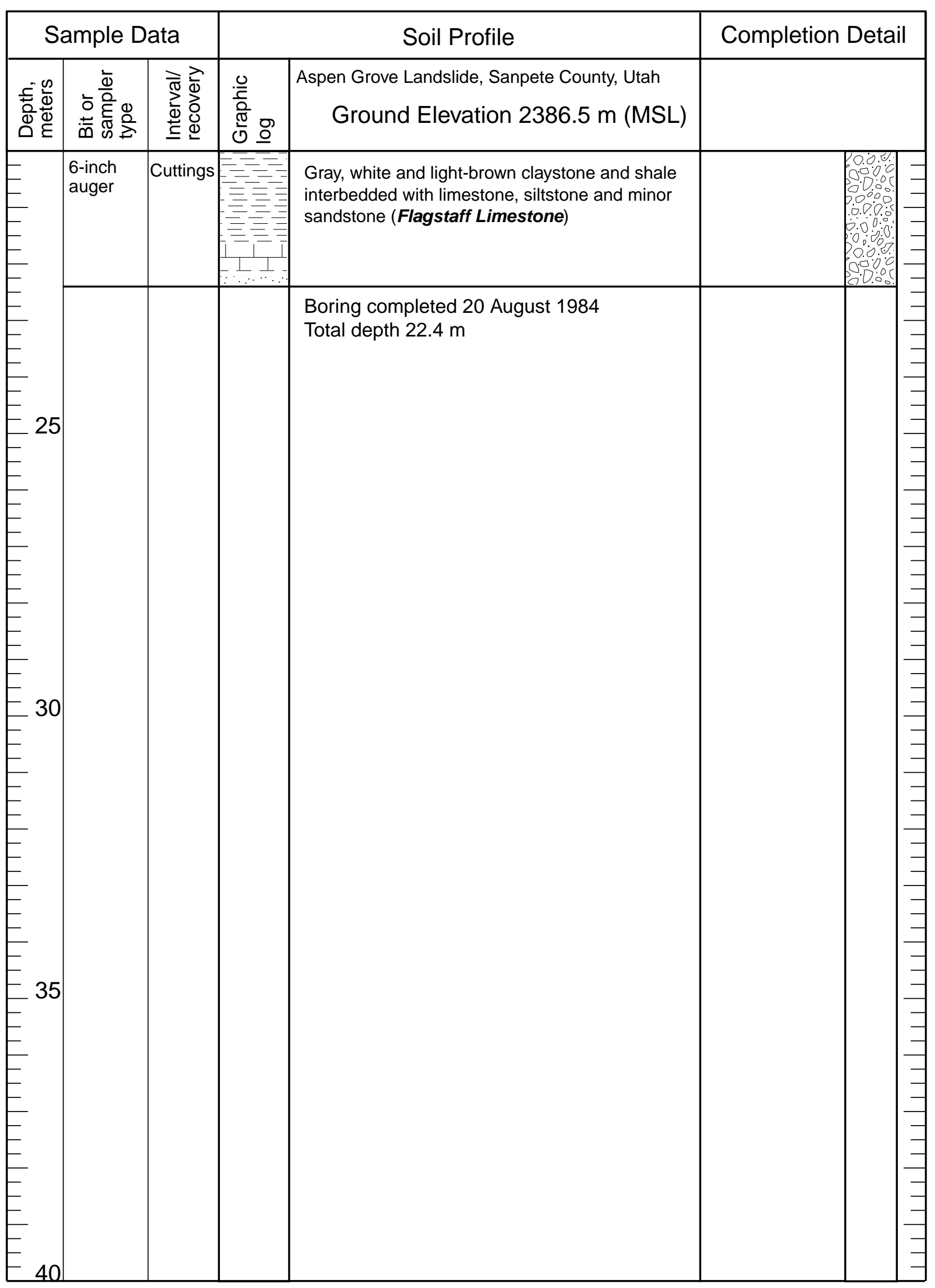




\section{Appendix A. Borehole logs-continued}

B-3

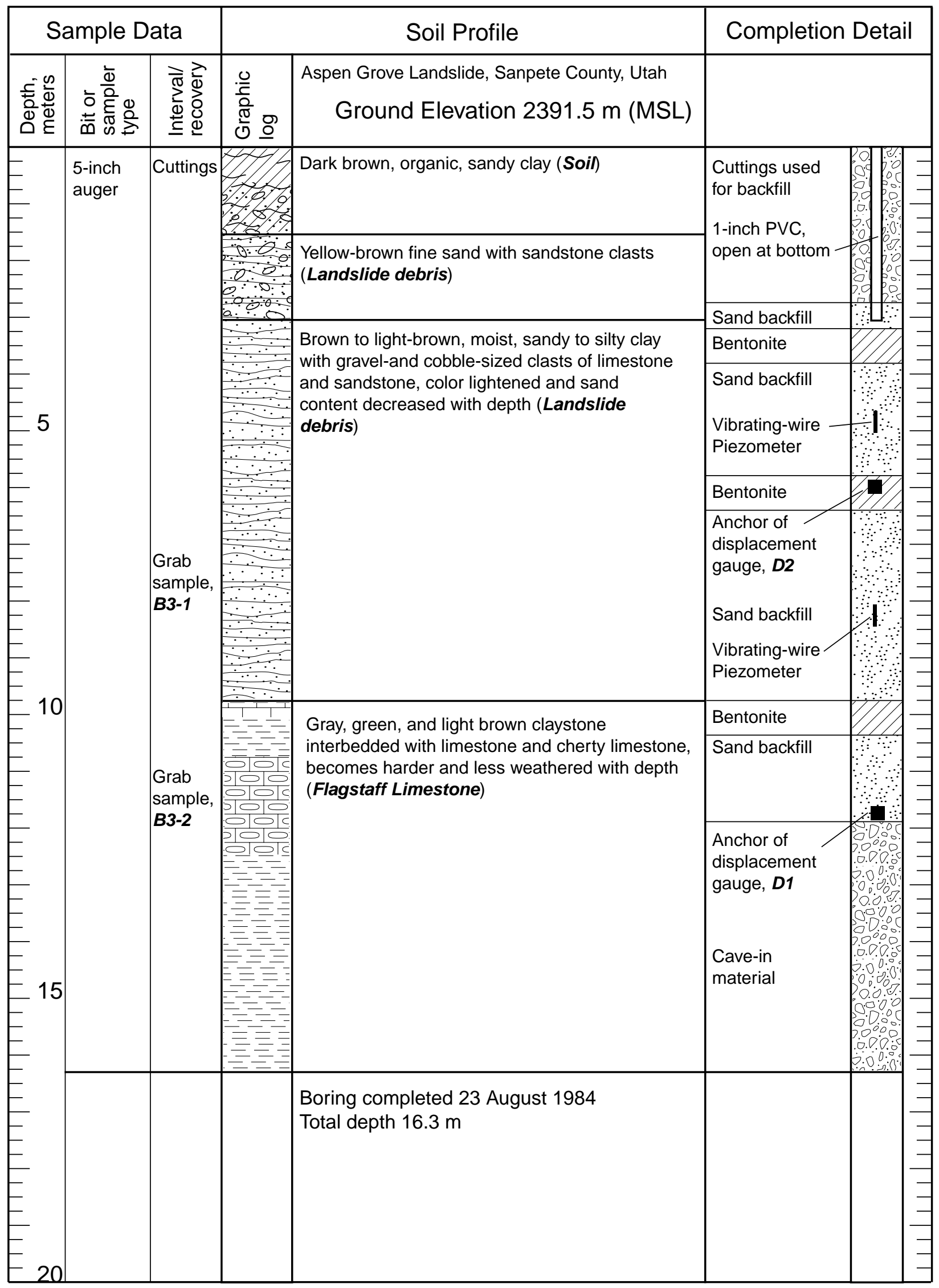




\section{Appendix A. Borehole logs-continued}

B-4

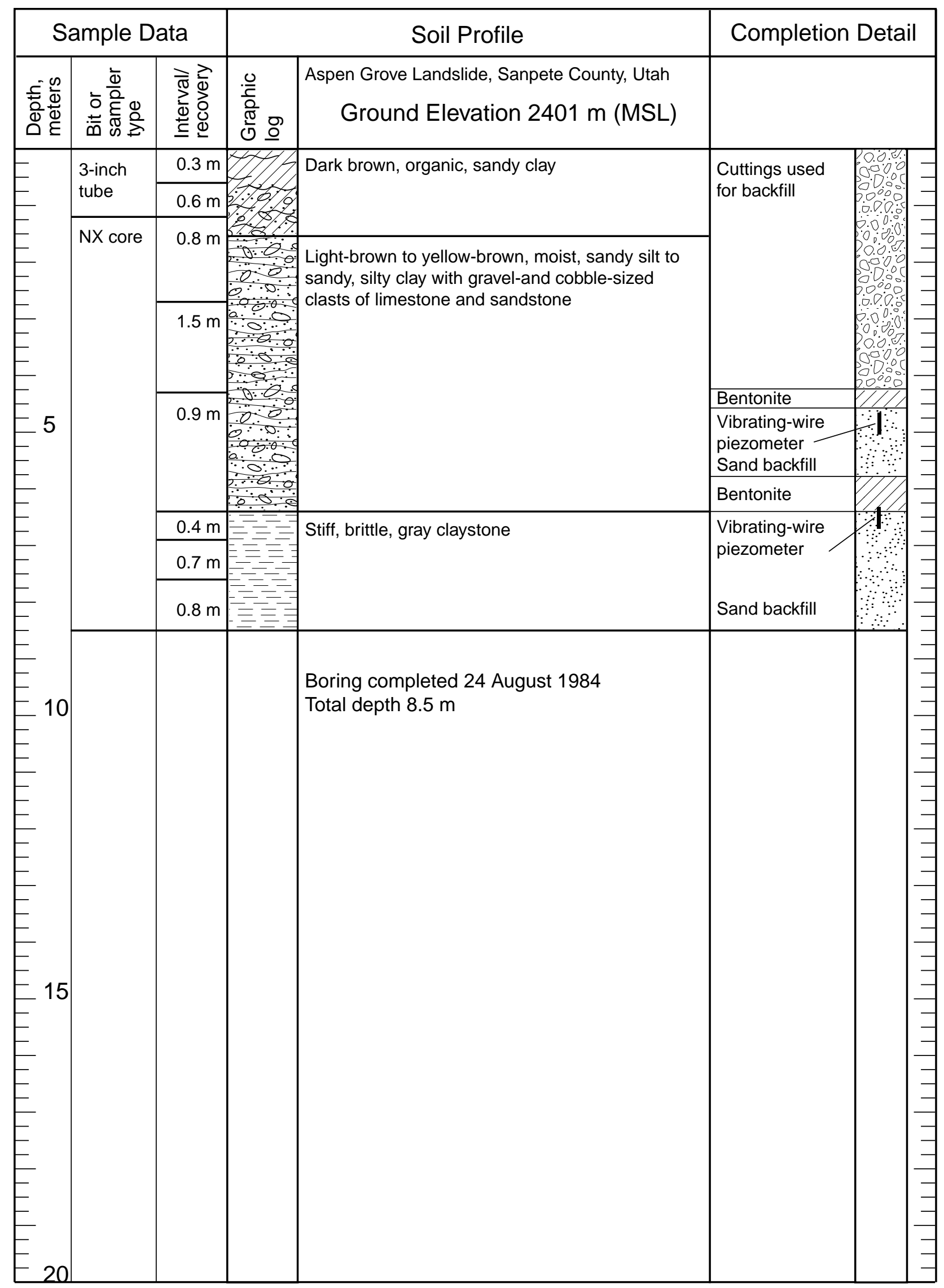




\section{Appendix A. Borehole logs-continued}

B-4

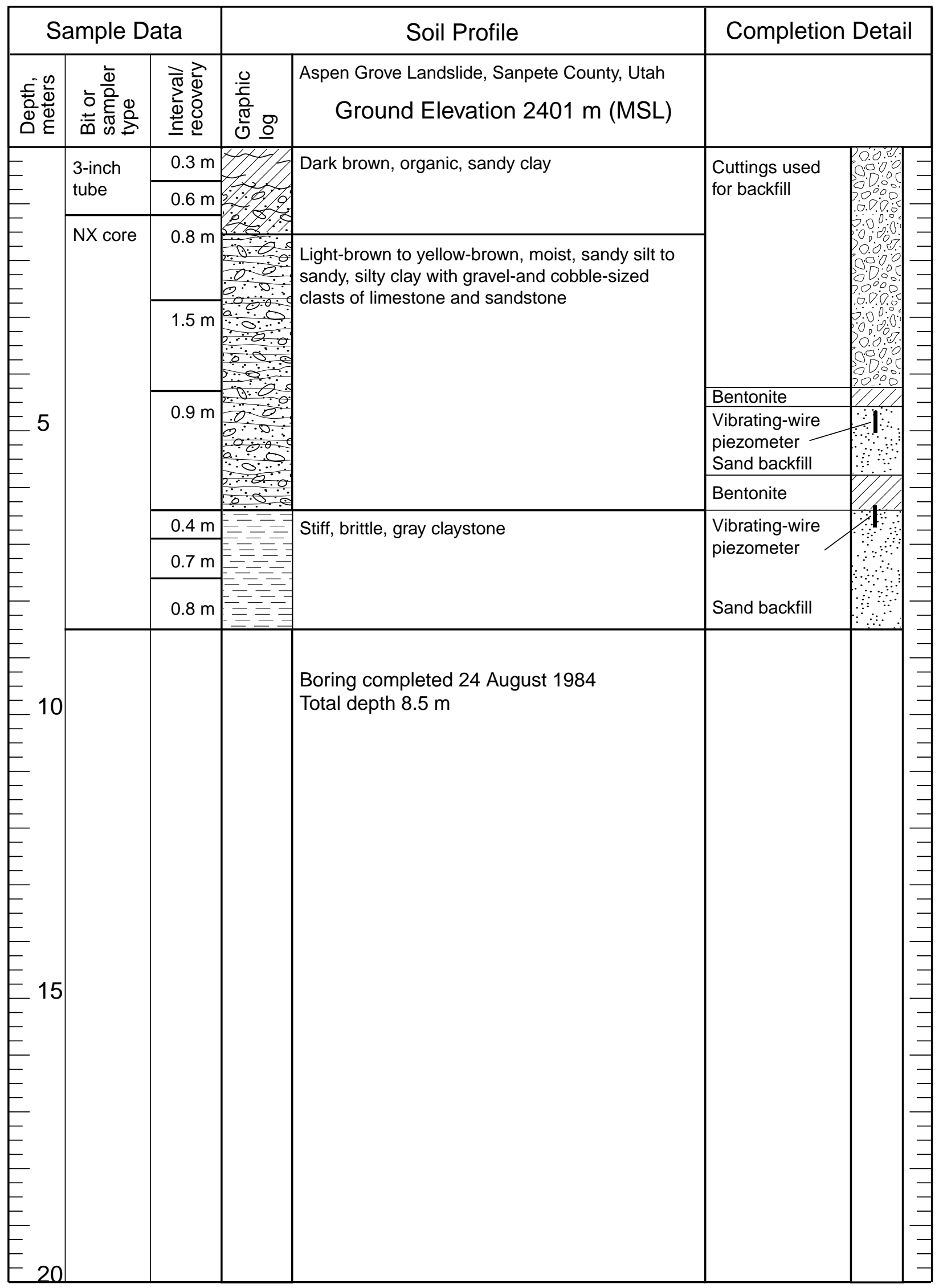




\section{Appendix A. Borehole logs-continued}

B-5

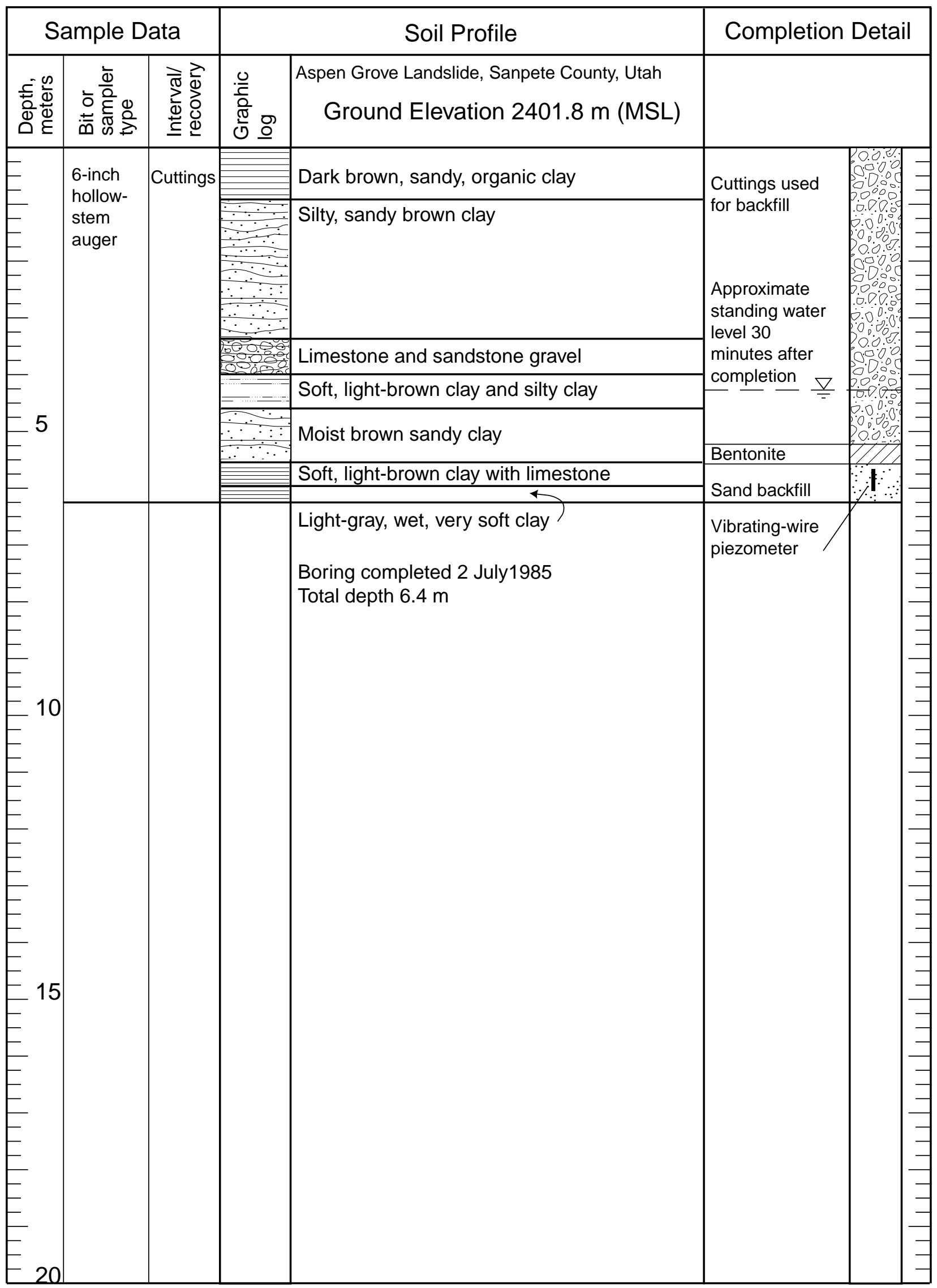




\section{Appendix A. Borehole logs-continued}

B-6

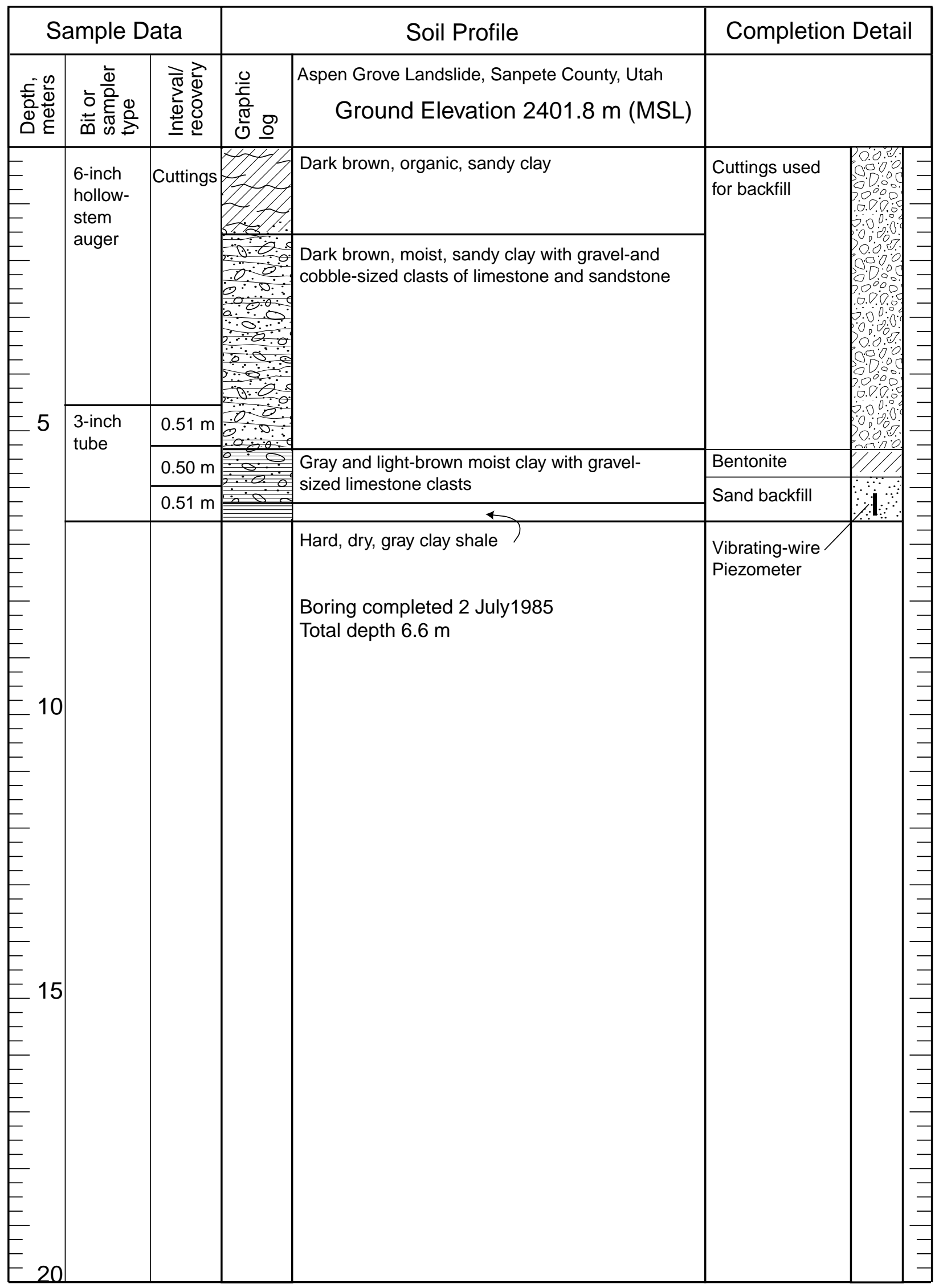




\section{Appendix B. Stress-displacement plots of direct-shear and torsional-shear test}

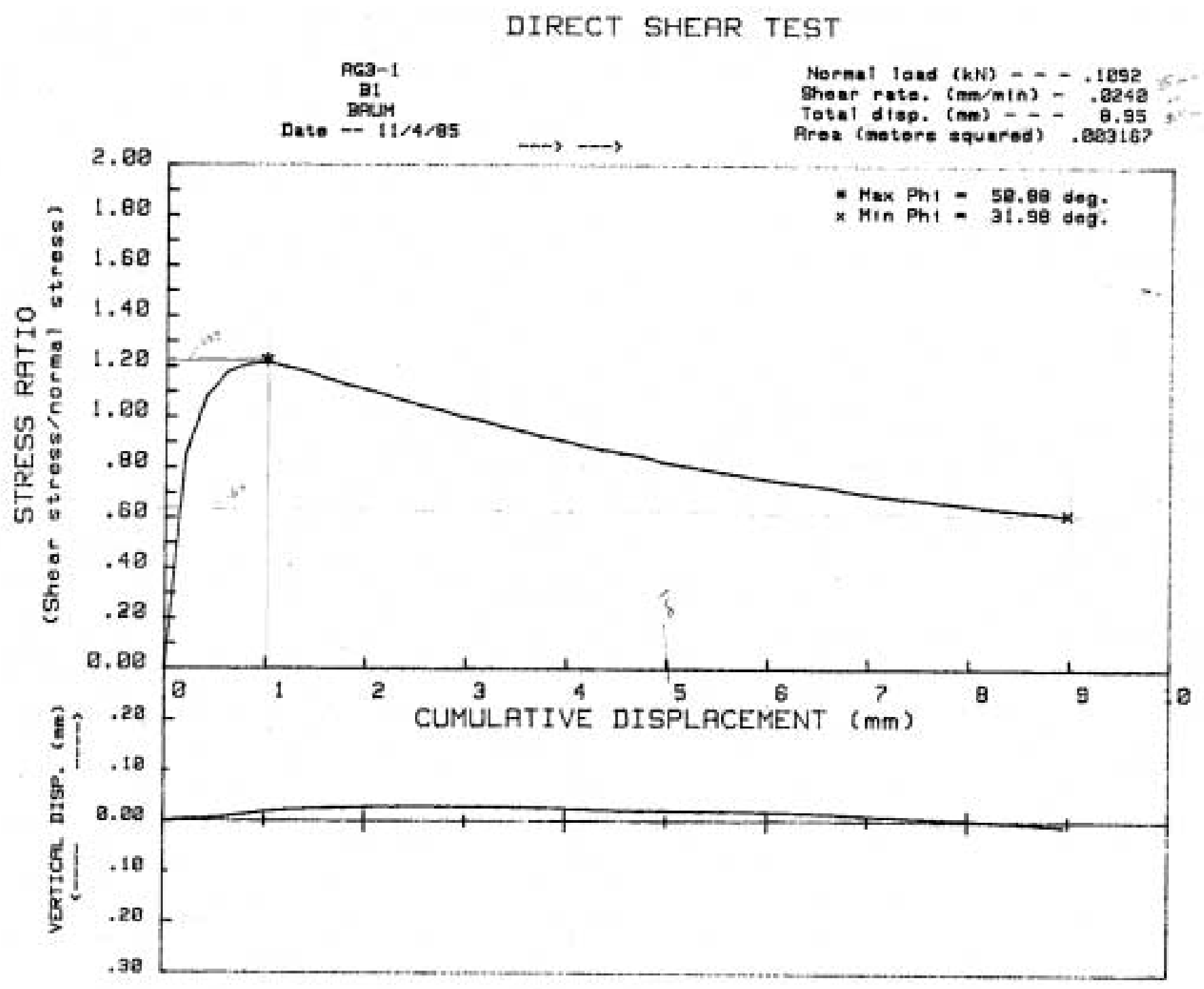




\section{Appendix B. Stress-displacement plots of direct-shear and torsional-shear test-Continued}

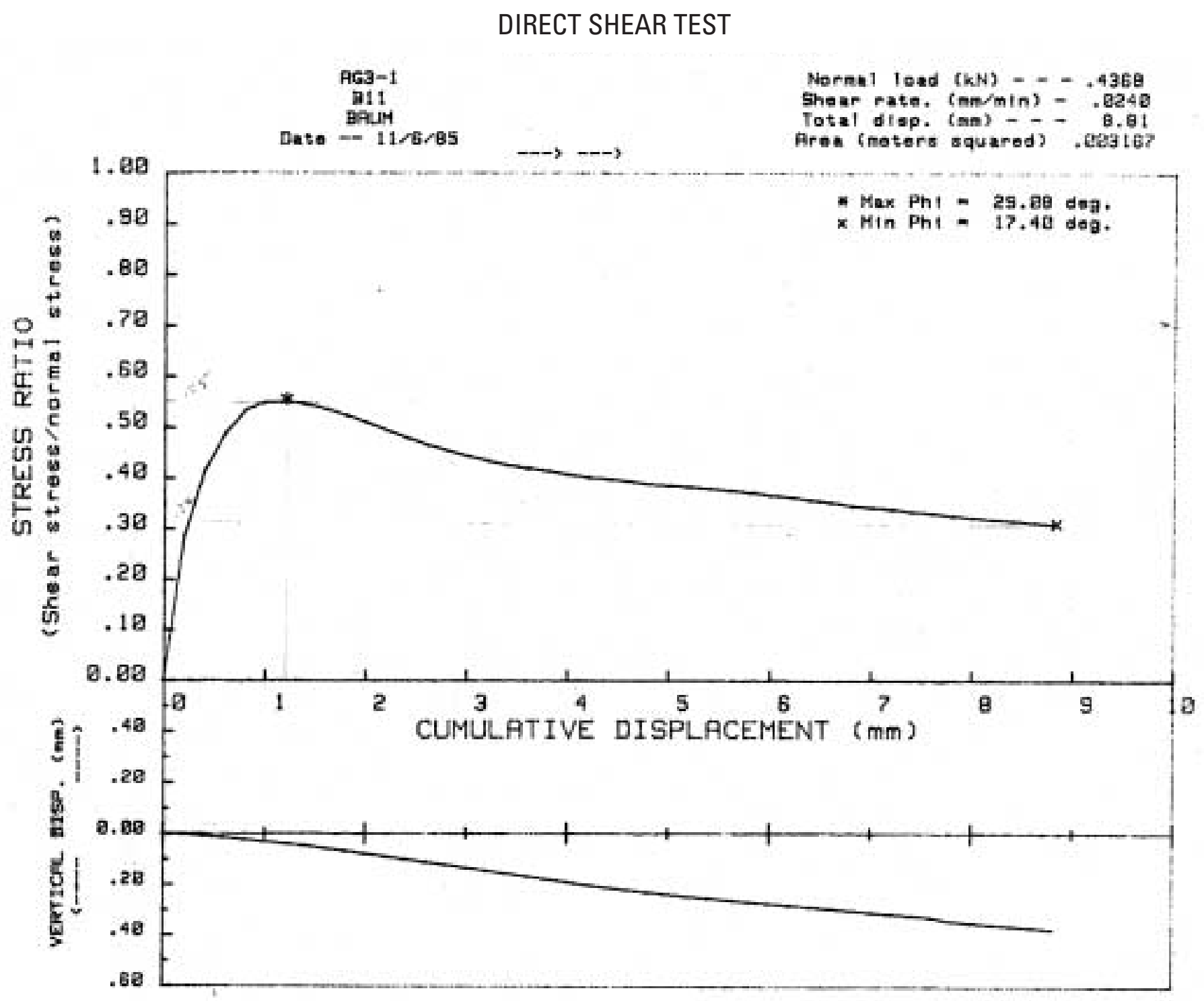




\section{Appendix B. Stress-displacement plots of direct-shear and torsional-shear test-Continued}

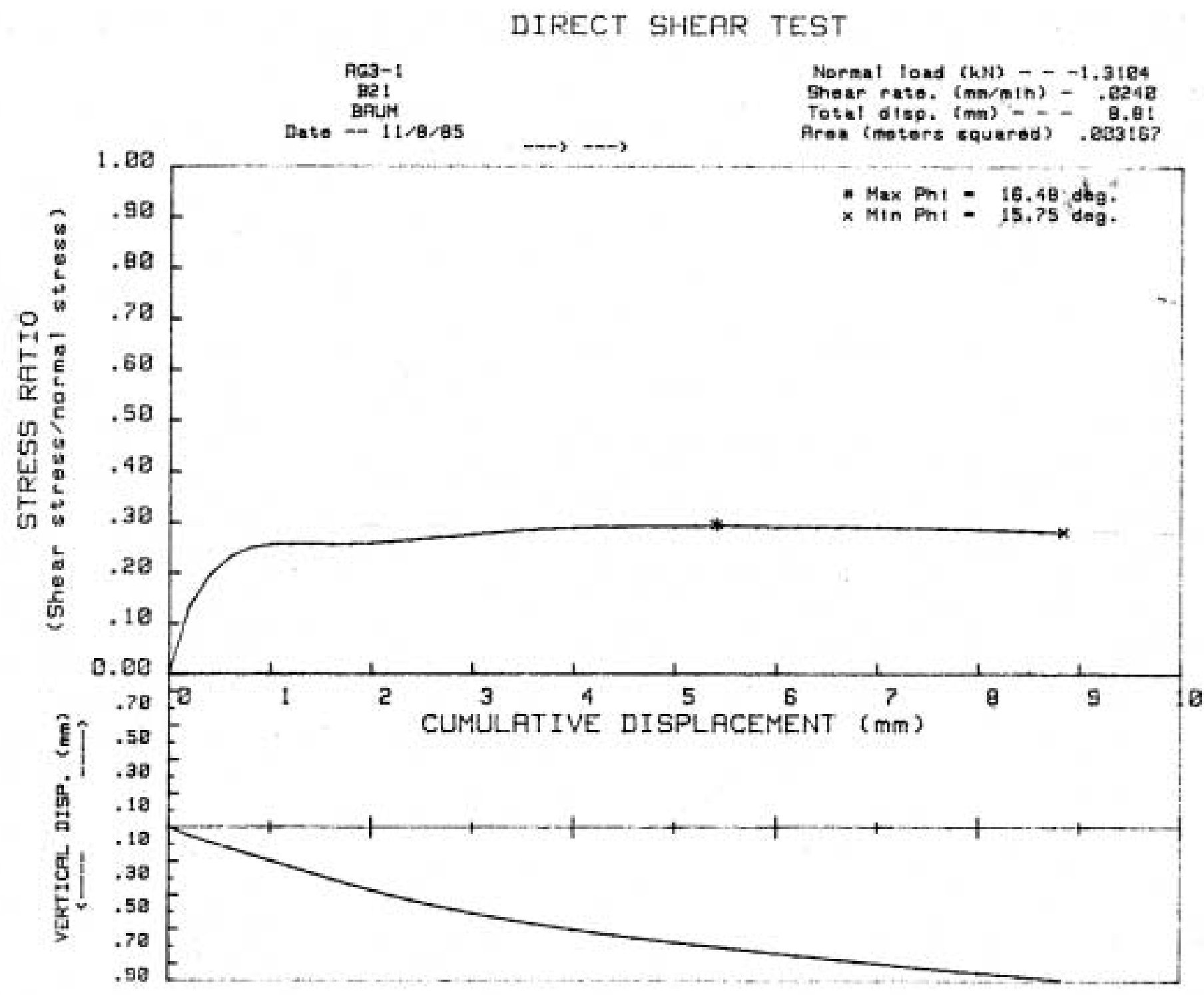




\section{Appendix B. Stress-displacement plots of direct-shear and torsional-shear test-Continued}

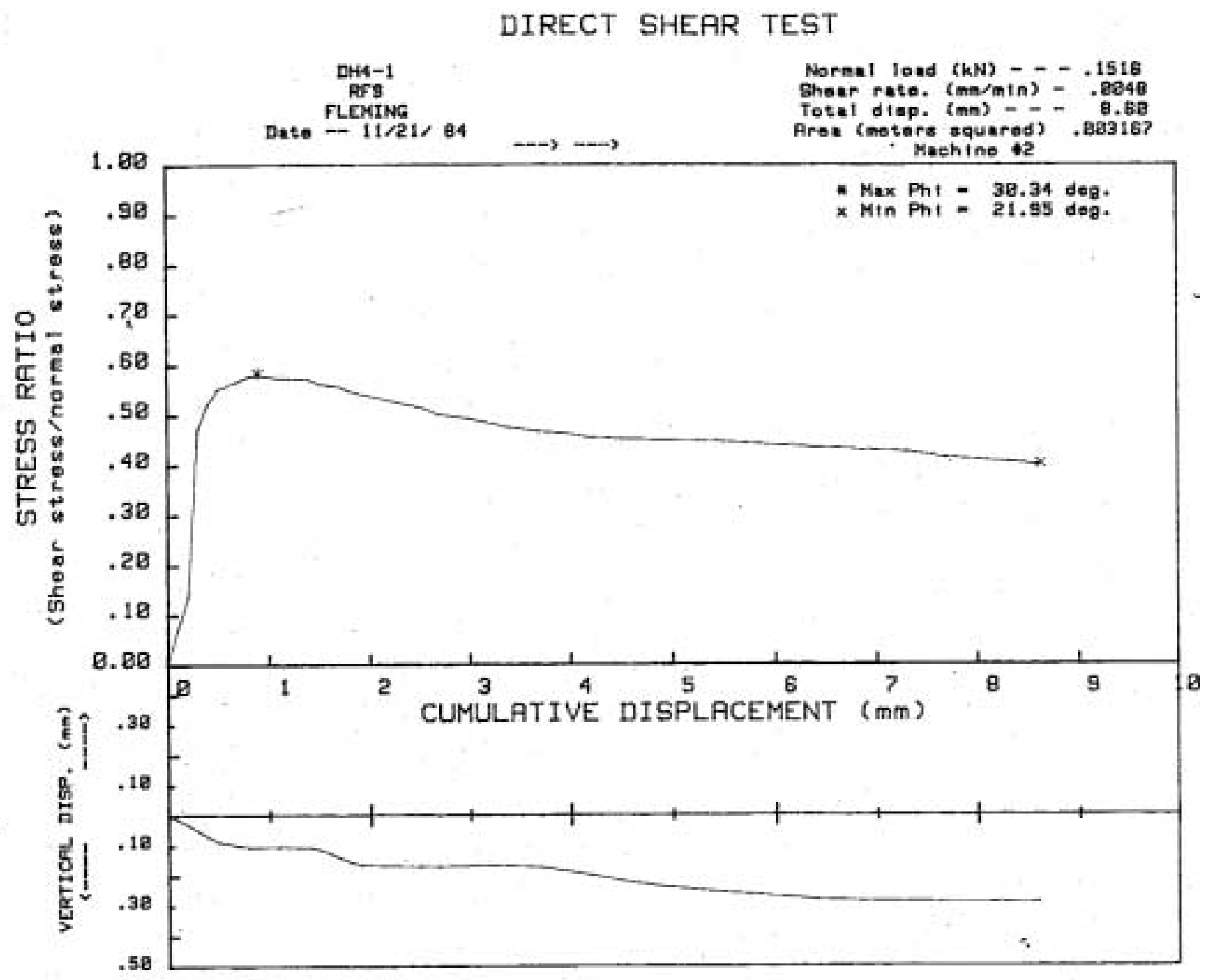




\section{Appendix B. Stress-displacement plots of direct-shear and torsional-shear test-Continued}

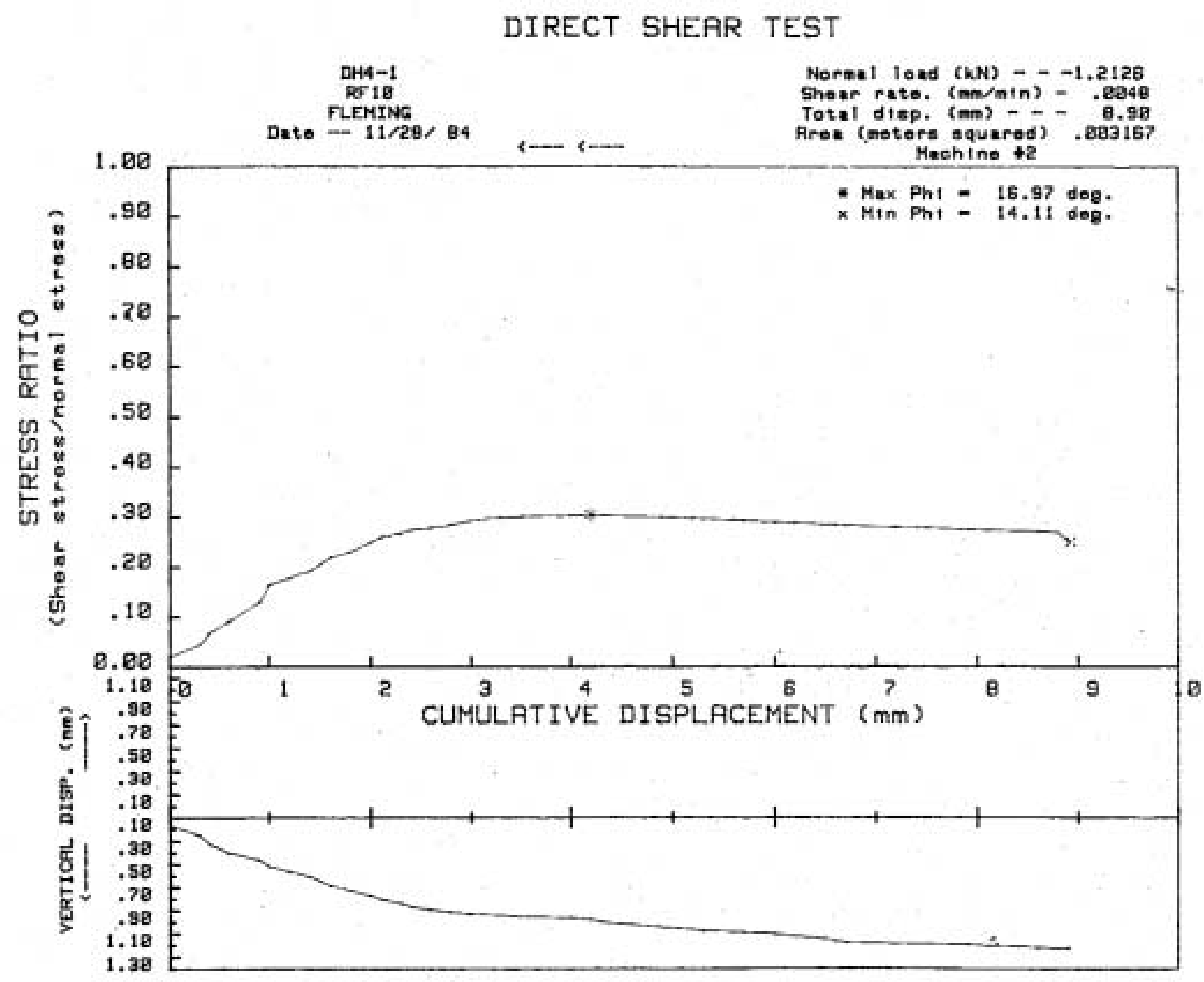




\section{Appendix B. Stress-displacement plots of direct-shear and torsional-shear test-Continued}

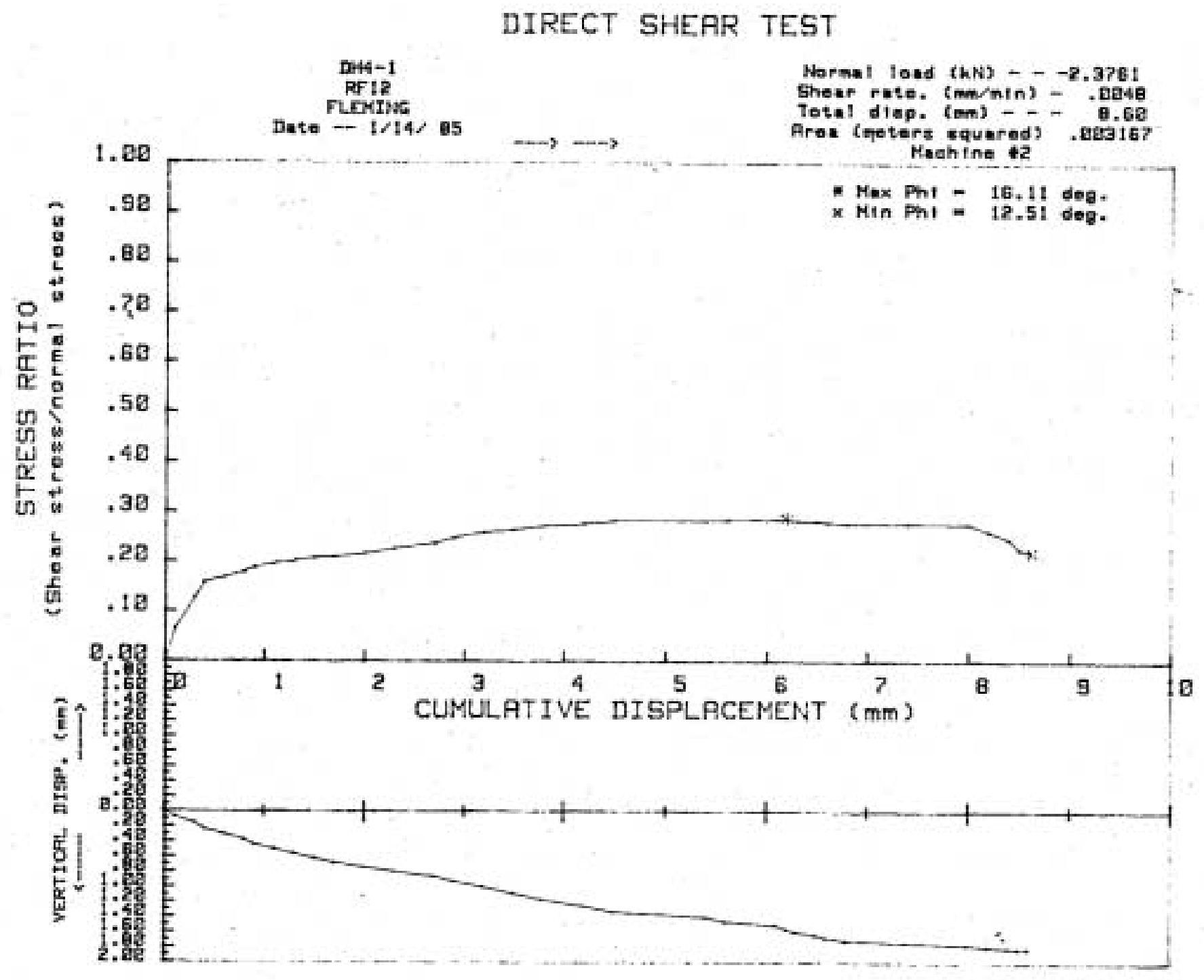




\section{Appendix B. Stress-displacement plots of direct-shear and torsional-shear test-Continued}

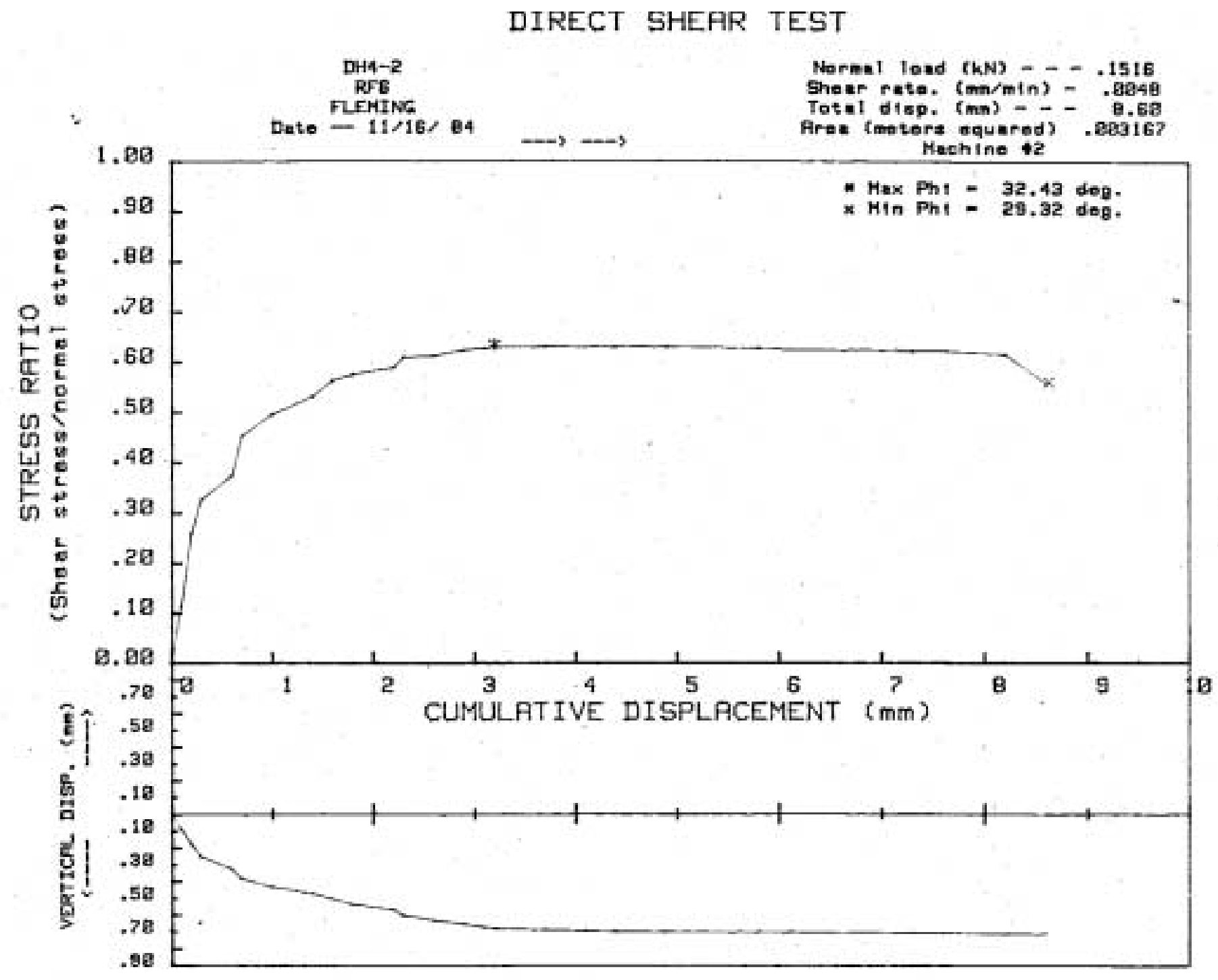




\section{Appendix B. Stress-displacement plots of direct-shear and torsional-shear test-Continued}

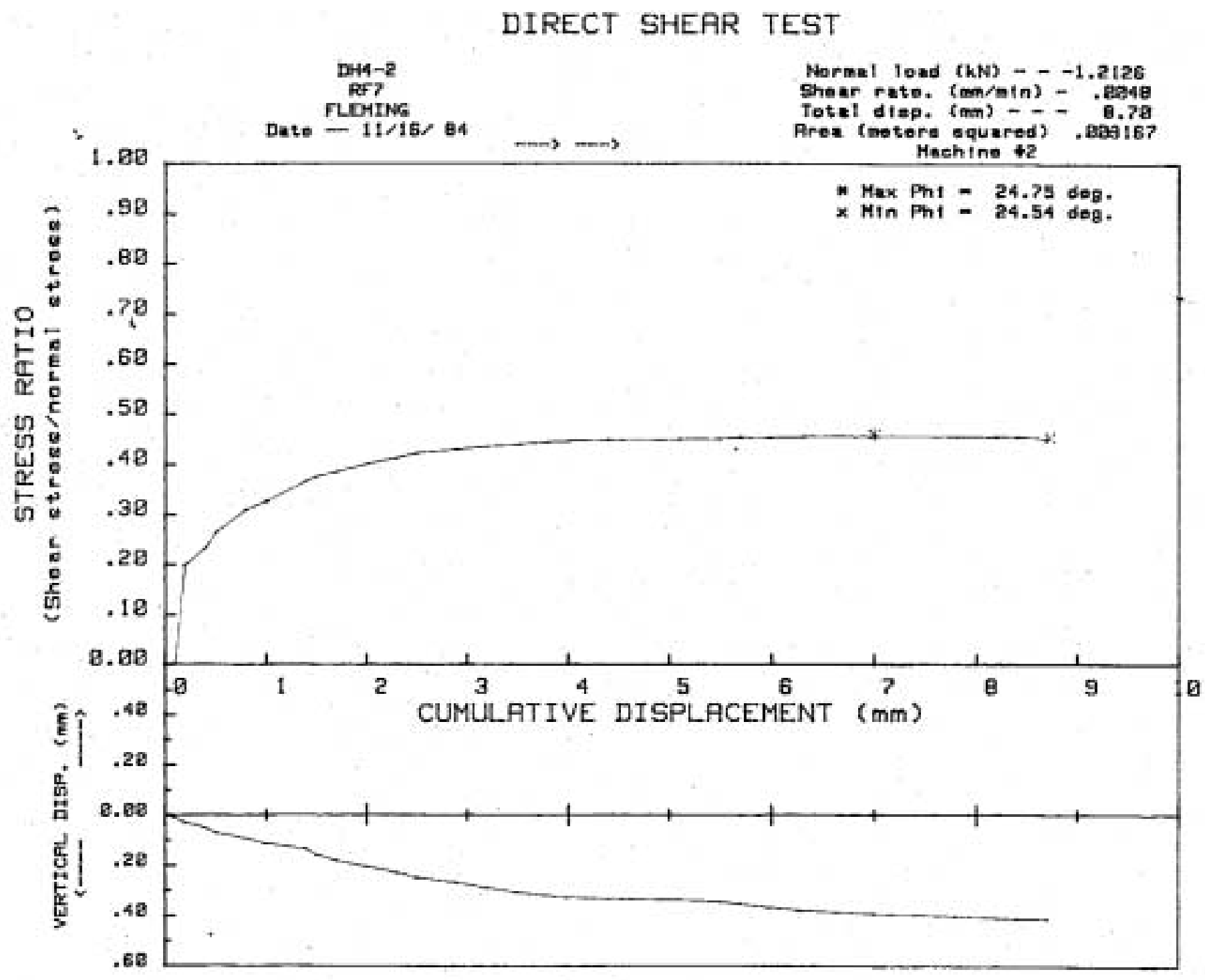




\section{Appendix B. Stress-displacement plots of direct-shear and torsional-shear test-Continued}

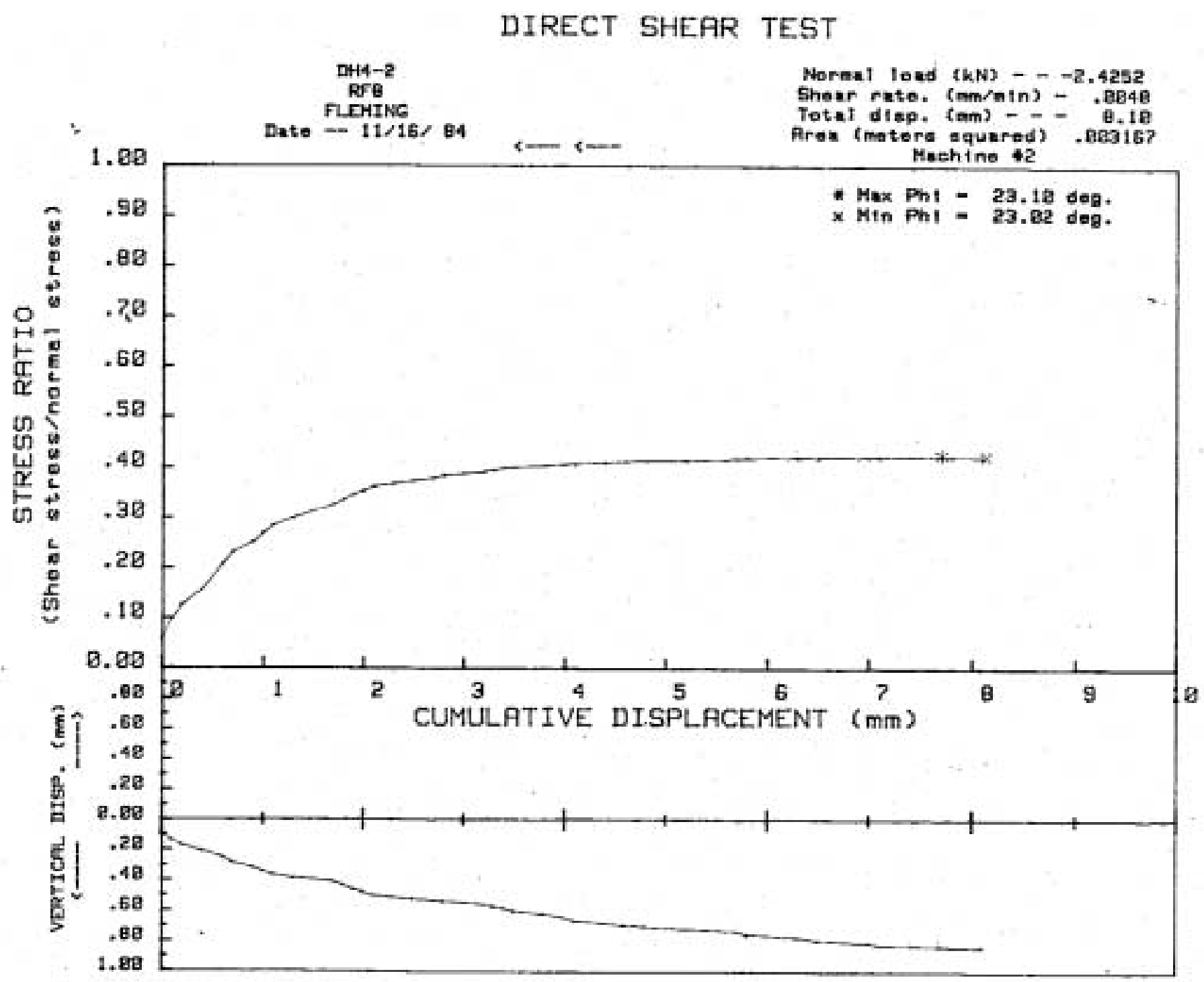




\section{Appendix B. Stress-displacement plots of direct-shear and torsional-shear test-Continued}

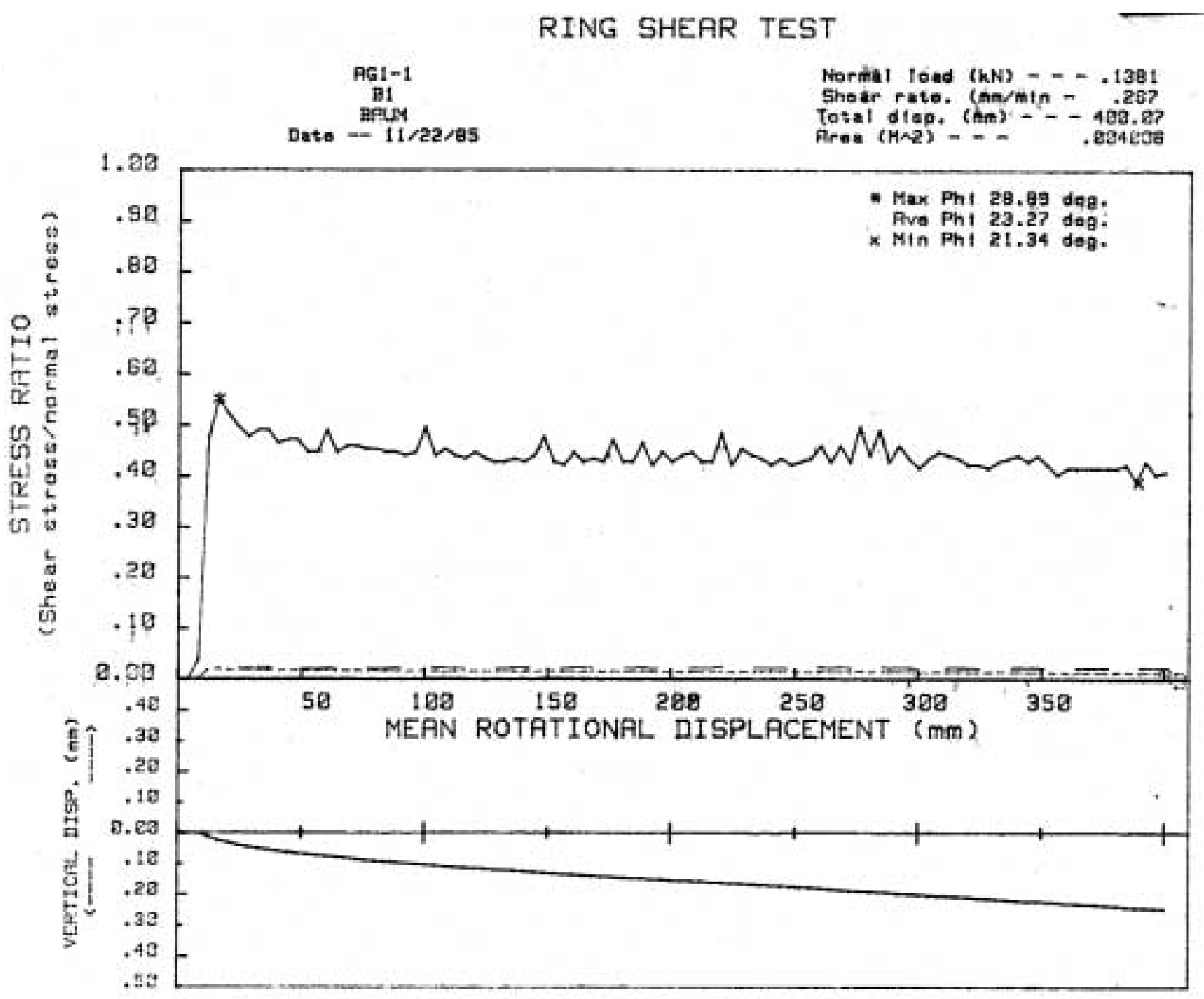




\section{Appendix B. Stress-displacement plots of direct-shear and torsional-shear test-Continued}

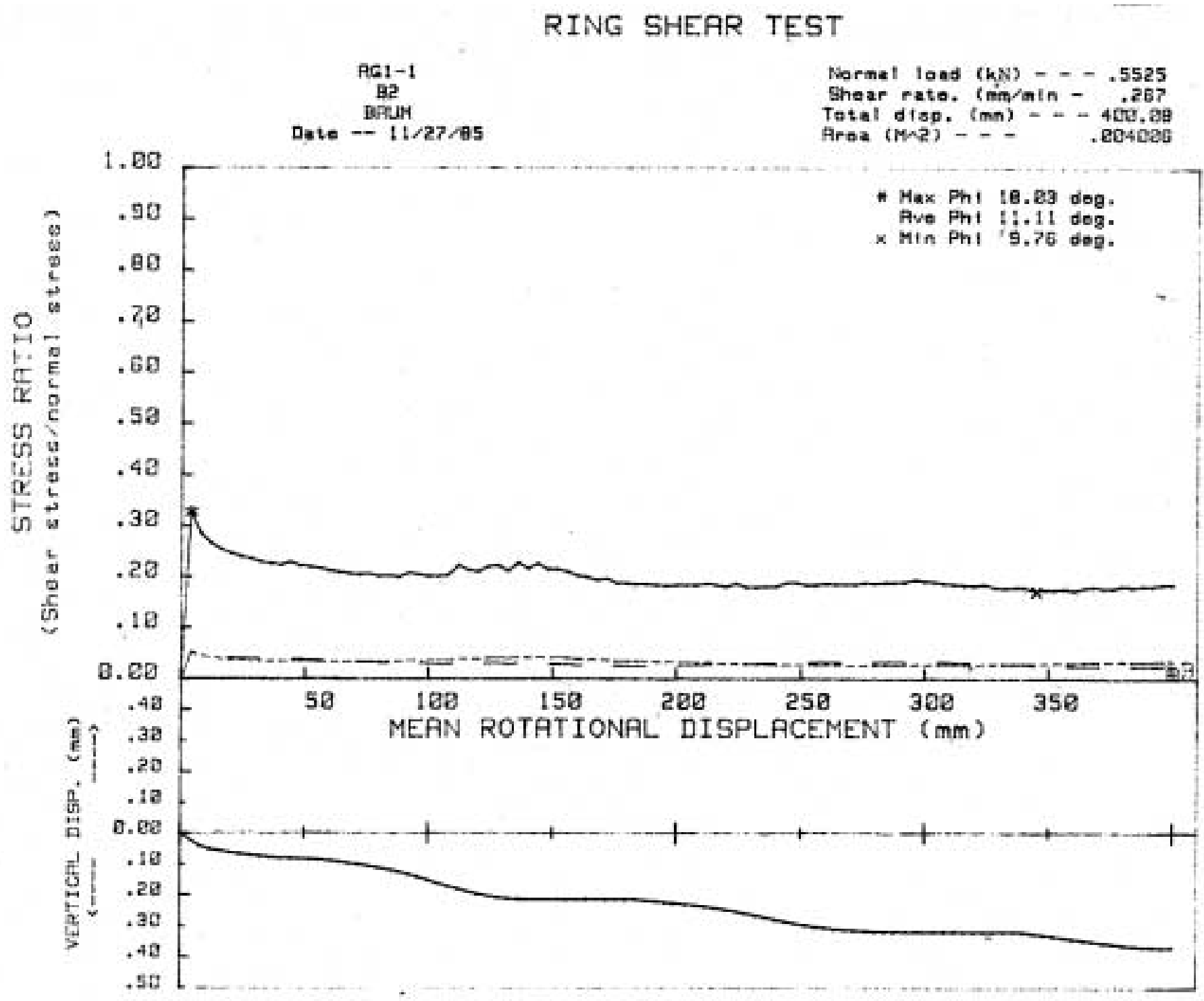




\section{Appendix B. Stress-displacement plots of direct-shear and torsional-shear test-Continued}

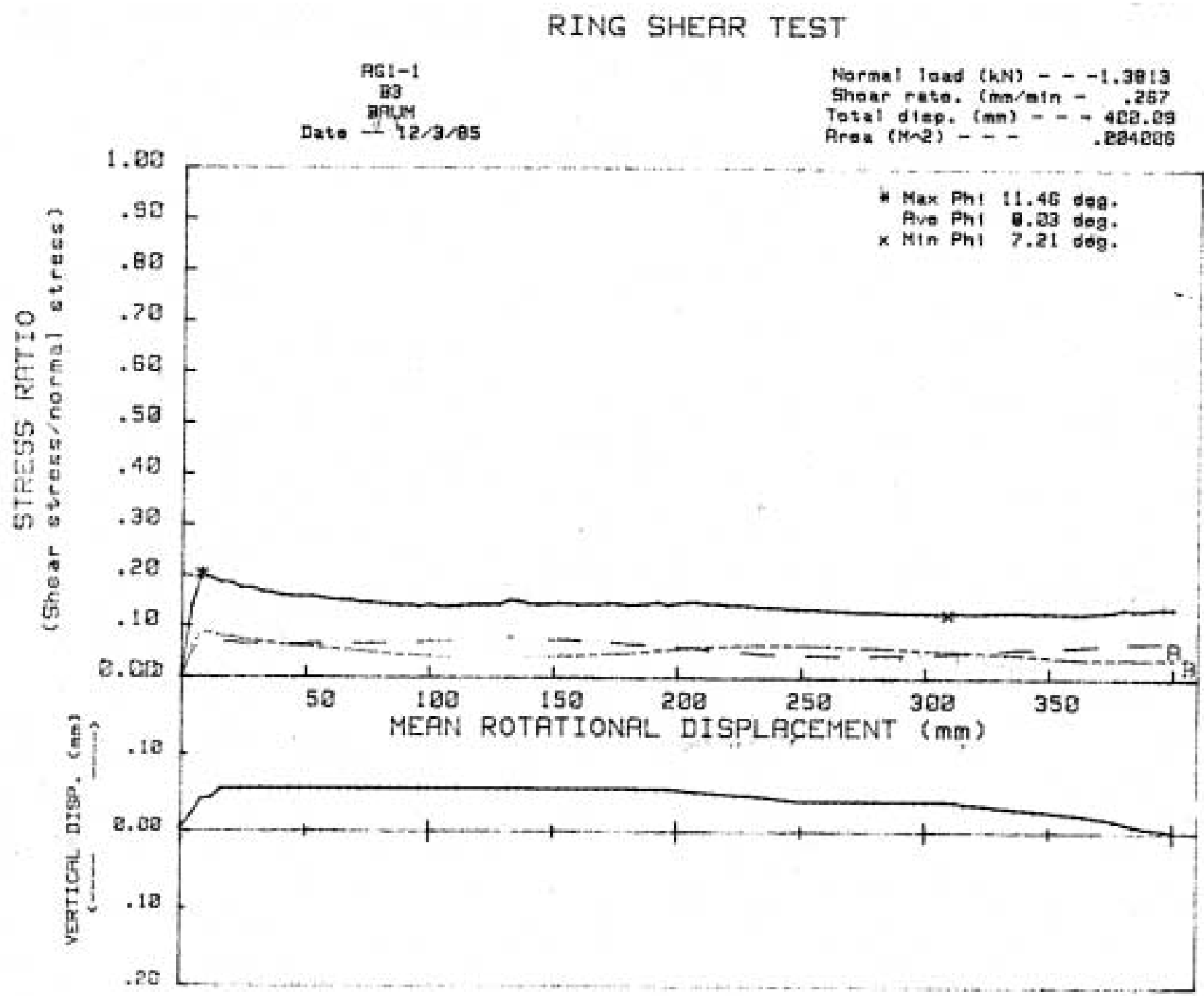




\section{Appendix B. Stress-displacement plots of direct-shear and torsional-shear test-Continued}

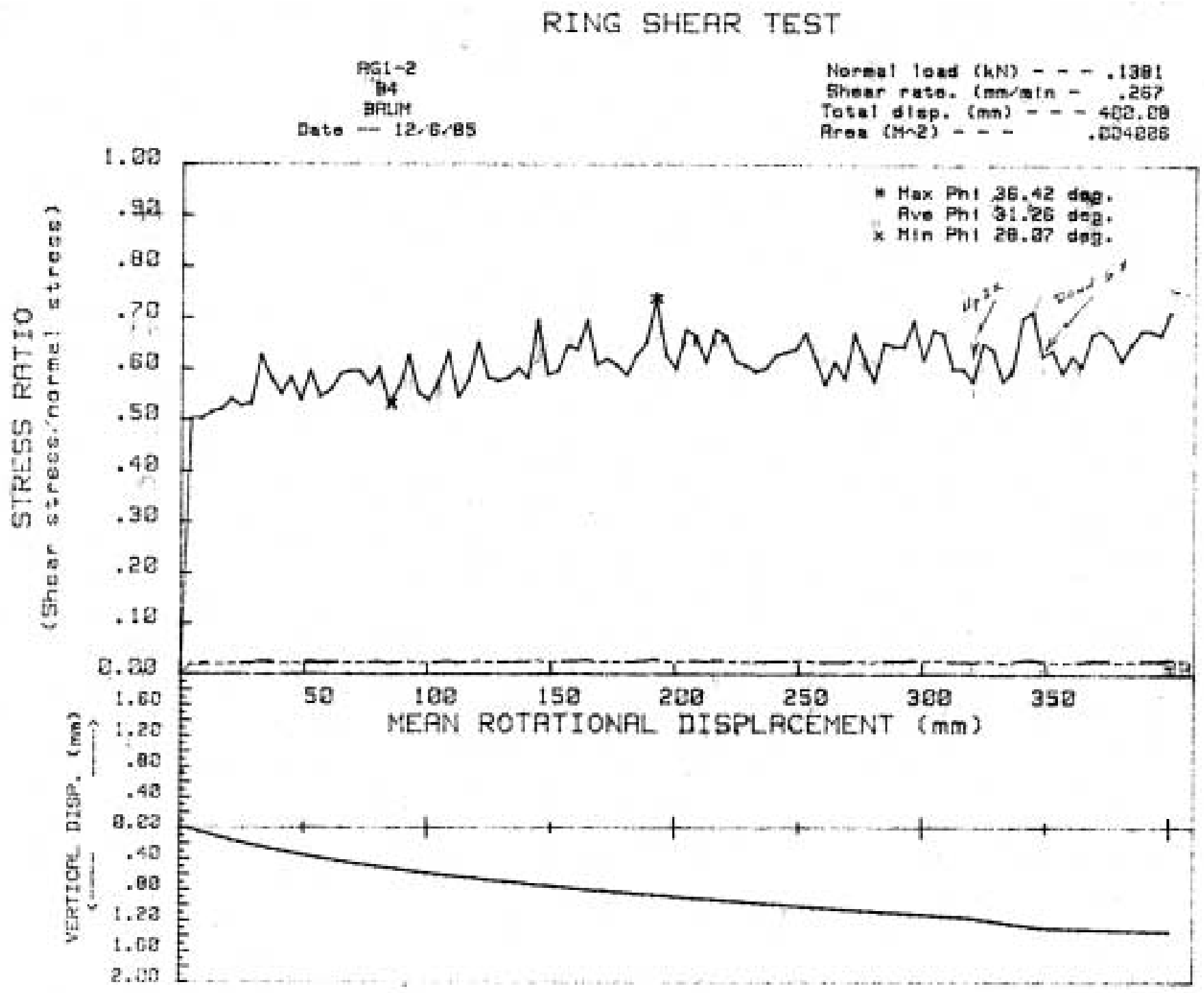




\section{Appendix B. Stress-displacement plots of direct-shear and torsional-shear test-Continued}

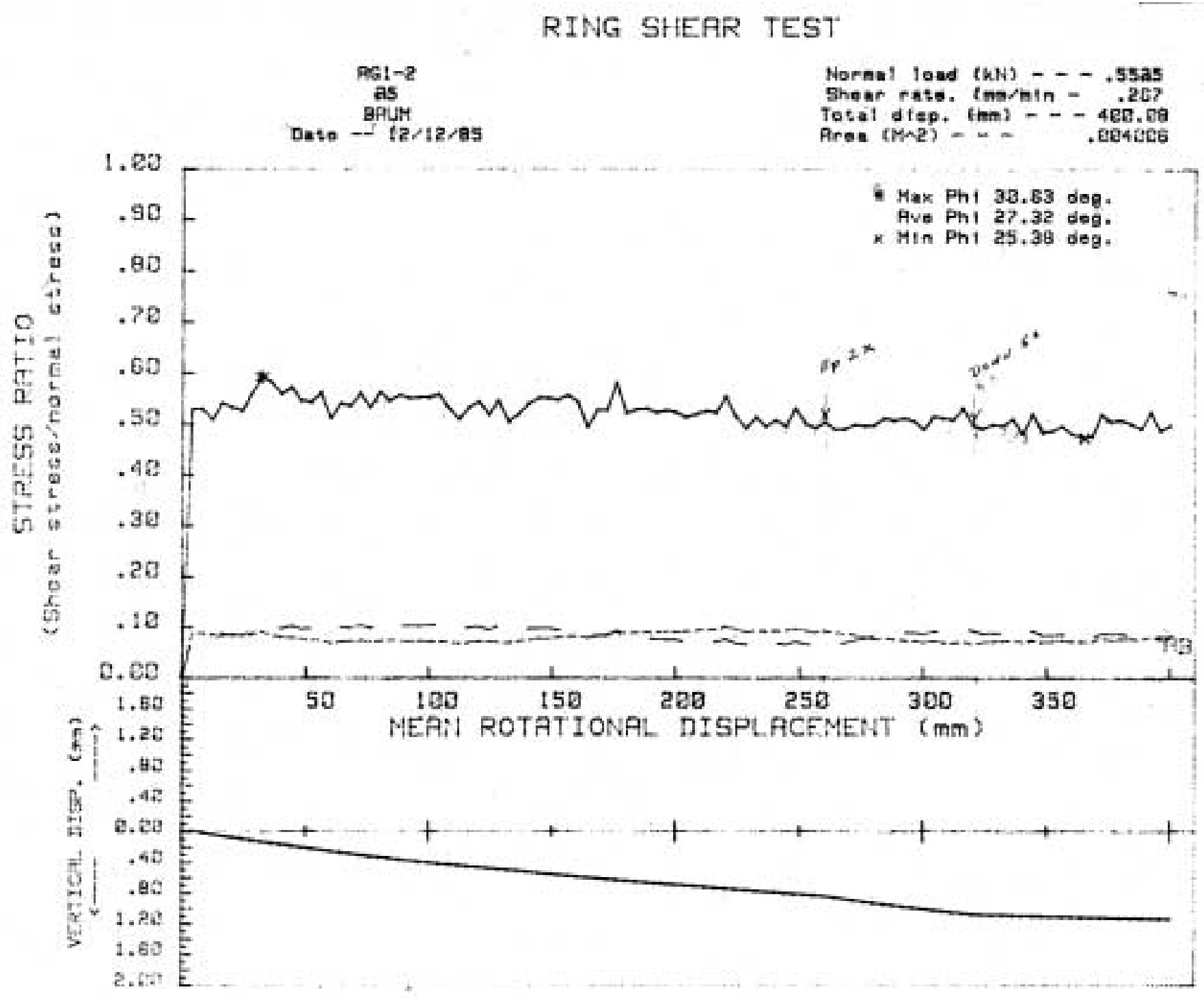




\section{Appendix B. Stress-displacement plots of direct-shear and torsional-shear test-Continued}

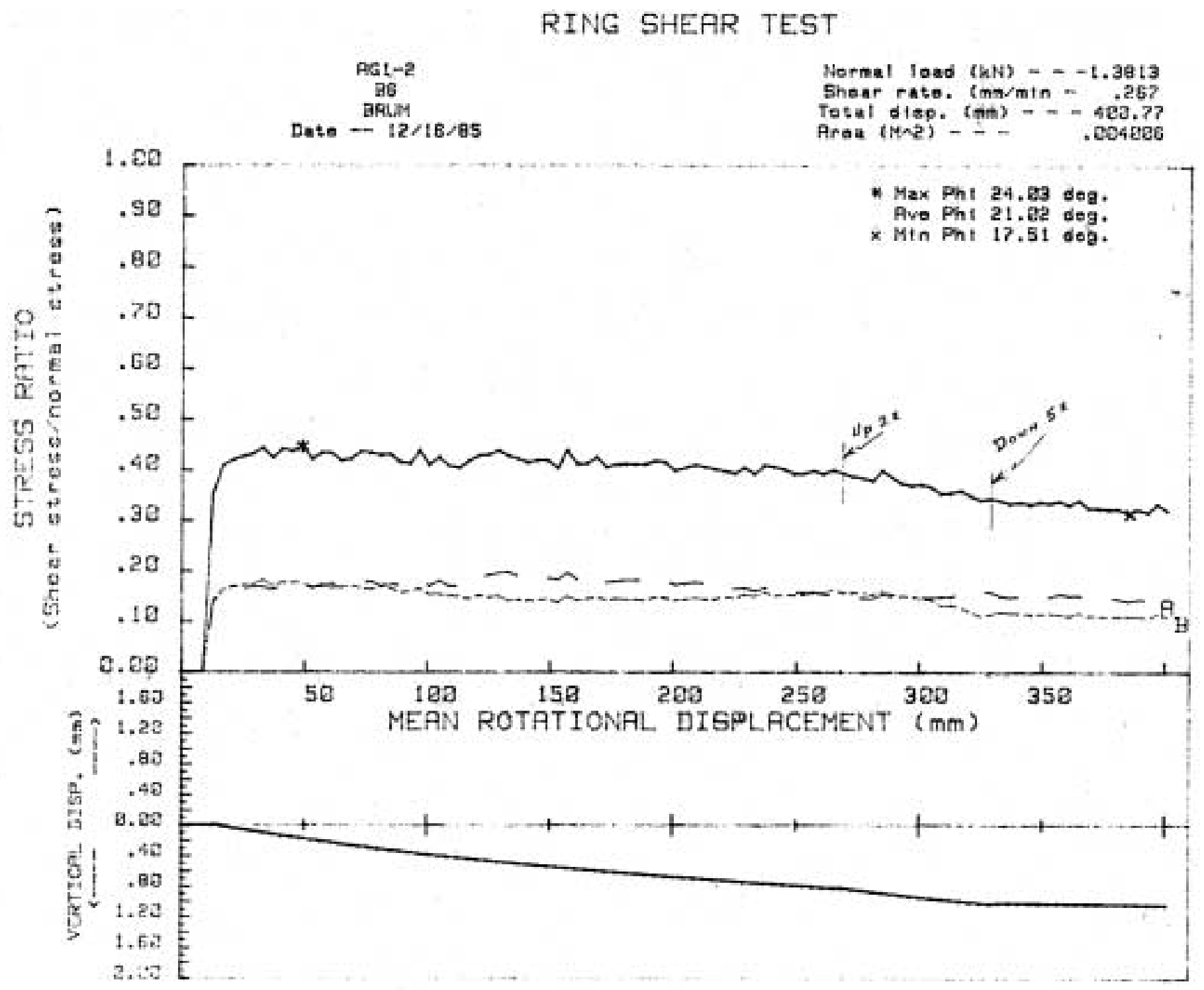




\section{Appendix B. Stress-displacement plots of direct-shear and torsional-shear test-Continued}

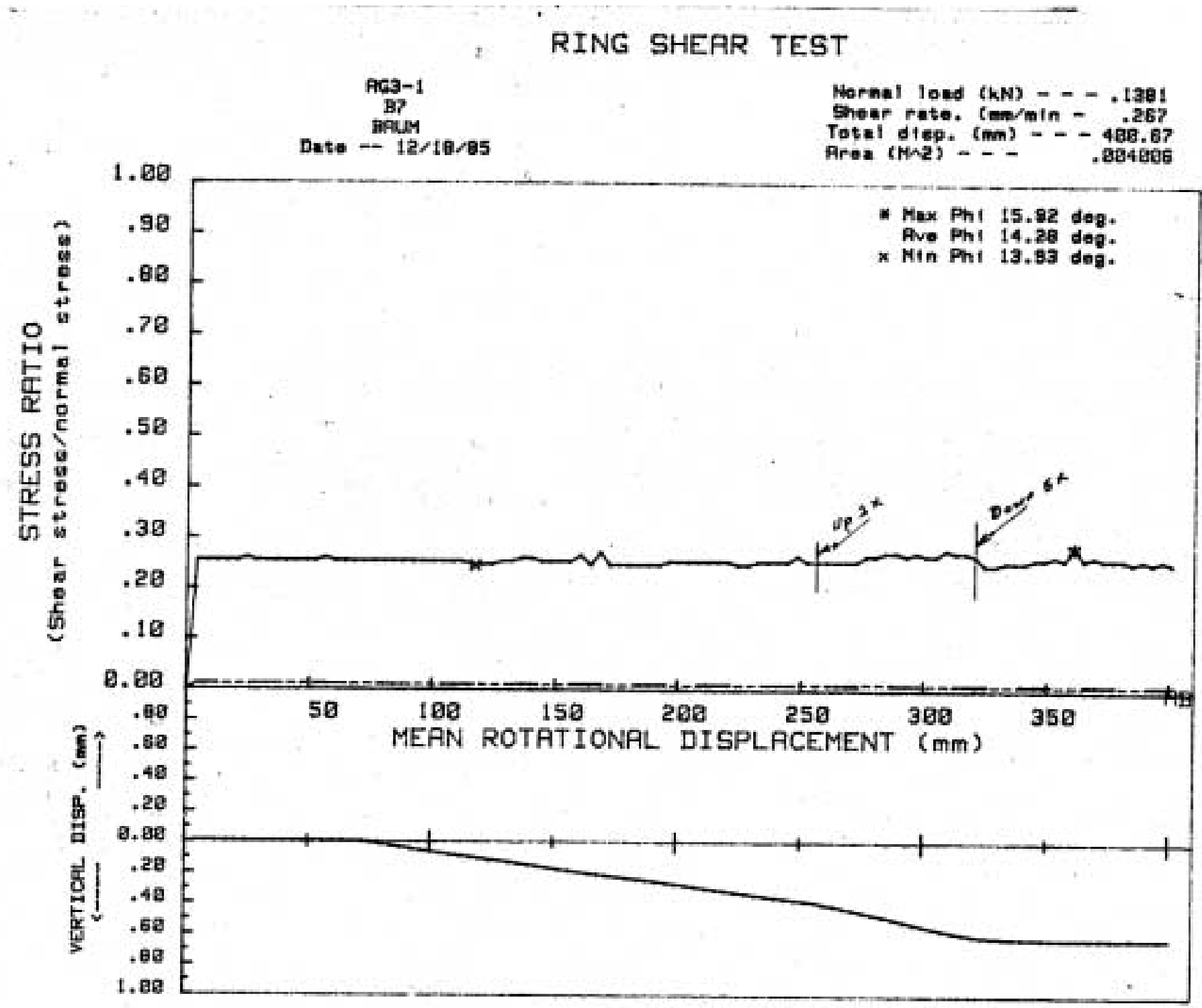




\section{Appendix B. Stress-displacement plots of direct-shear and torsional-shear test-Continued}

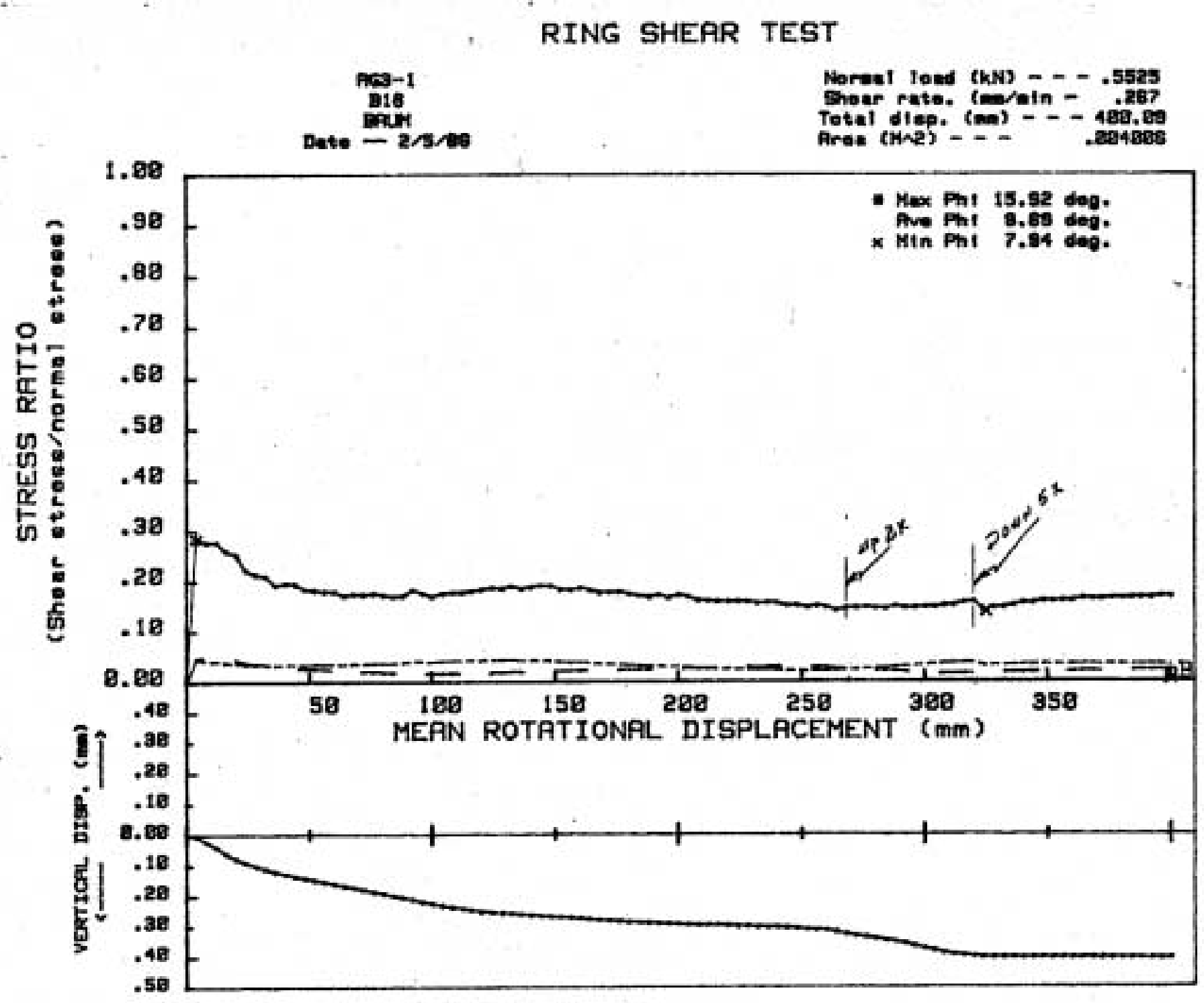




\section{Appendix B. Stress-displacement plots of direct-shear and torsional-shear test-Continued}

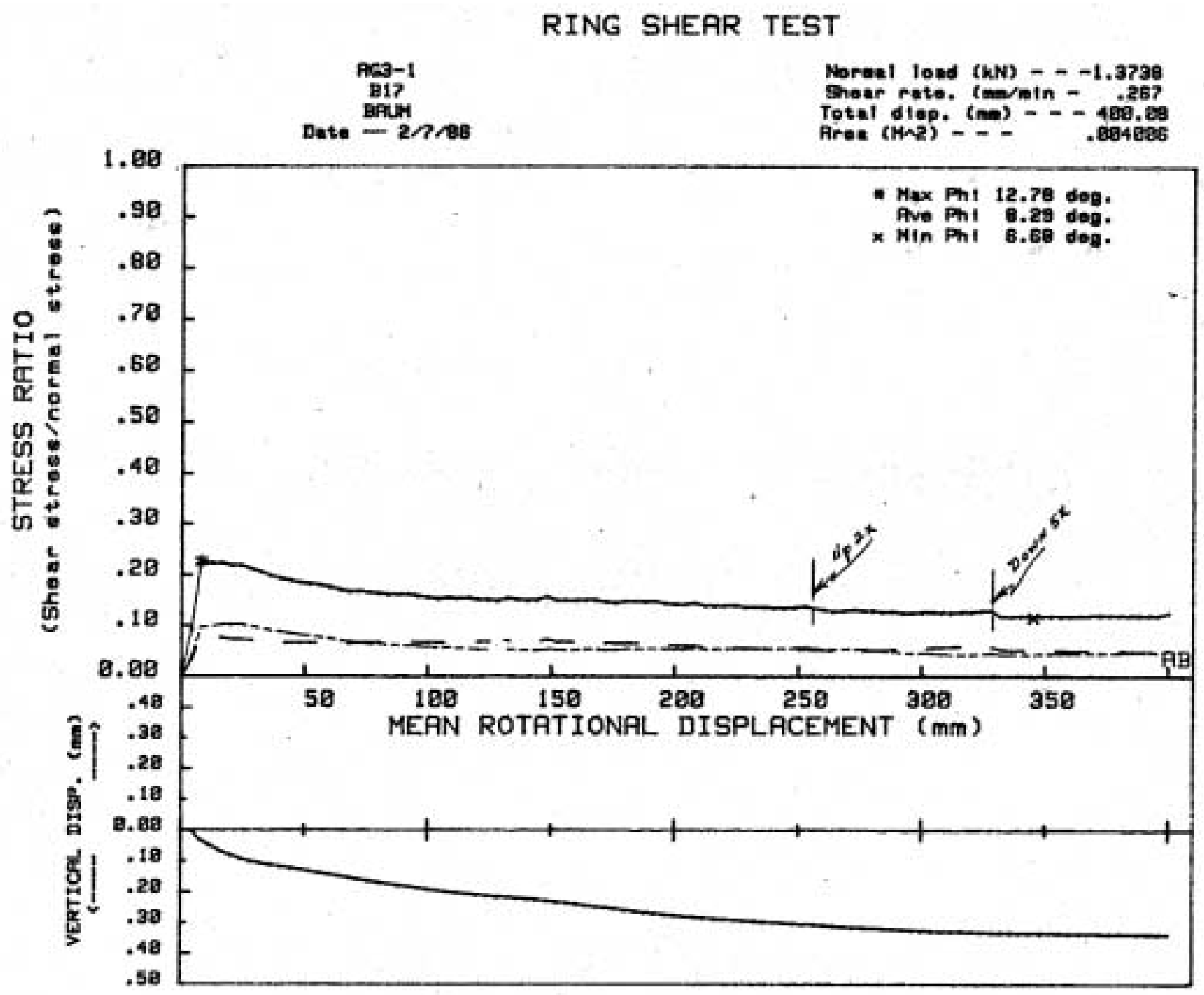

